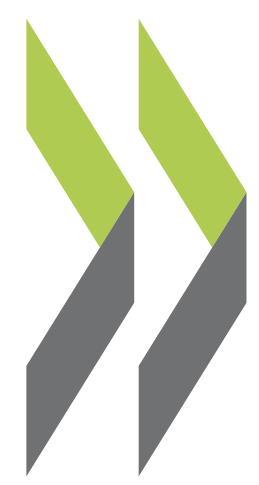

OECD Economics Department Working Papers No. 161

\author{
Innovation, Firm Size \\ and Market Structure:
}

Schumpeterian Hypotheses and Some New Themes

\title{
George Symeonidis
}




\author{
ECONOMICS DEPARTMENT \\ WORKING PAPERS \\ NO. 161 \\ INNOVATION, FIRM SIZE AND MARKET STRUCTURE: \\ SCHUMPETERIAN HYPOTHESES AND SOME NEW THEMES \\ by \\ George Symeonidis \\ London School of Economics
}

ORGANISATION FOR ECONOMIC CO-OPERATION AND DEVELOPMENT

Paris 1996

32643

Document complet disponible sur OLIS dans son format d'origine

Complete document available on OLIS in its original format 


\section{INNOVATION, FIRM SIZE AND MARKET STRUCTURE: SCHUMPETERIAN HYPOTHESES AND SOME NEW THEMES}

This paper surveys the empirical literature on the links between innovation, market structure and firm size. The review shows that there is little evidence in support of the Schumpeterian hypothesis that market power and large firms stimulate innovations: R\&D spending seems to rise more or less proportionally with firm size after a certain threshold level has been passed, and there is little evidence of a positive relationship between R\&D intensity and concentration in general. However, positive linkages between concentration/size and innovative activity can occur when certain conditions are met, including high sunk costs per individual project, economies of scale and scope in the production of innovation rents. Recent empirical work suggests that R\&D intensity and market structure are jointly determined by technology, the characteristics of demand, the institutional framework, strategic interaction and chance.

$* * * * *$

Cet article passe en revue la littérature empirique concernant les liens entre innovation, structure de marché et taille de l'entreprise. Il montre le manque de preuves en faveur des hypothèses schumpeteriennes selon lesquelles l'innovation serait stimulée par la puissance du marché et l'existence de grosses sociétés : les dépenses de R-D semblent croître de manière plus ou moins proportionnelle avec la taille de l'entreprise après qu'un certain seuil a été franchi, et peu de signes attestent d'une relation positive entre intensité de la R-D et concentration en général. Cependant, des liens positifs entre concentration/taille et activité innovante peuvent s'établir sous certaines conditions, parmi lesquelles l'existence de coûts fixes élevés par projet individuel, d'économies d'échelle et de gamme dans la production d'innovations, de contraintes financières, et de difficultés à s'approprier les rentes liées à l'innovation. Des travaux empiriques récents semblent indiquer que l'intensité de la R-D et la structure du marché sont déterminées conjointement par la technologie, les caractéristiques de la demande, le cadre institutionnel, l'interaction stratégique, et le hasard.

\section{Copyright OECD, 1996}

Application for permission to reproduce or translate all, or part of this material, should be made to: Head of Publications Service, OECD, 2 rue André Pascal, 75775 Paris Cedex 16, France. 


\section{Introduction}

1. A central issue in industrial economics is how different market structures affect economic performance and social welfare. The exercise of monopoly power is known to result in static allocative inefficiency, although empirical estimates of the associated welfare loss vary widely. On the other hand, the static analysis of the social costs of monopoly (or oligopoly) fails to take into account the implications of alternative market structures for dynamic efficiency. A common argument in this context is that concentrated market structures may be favourable to technological progress, and hence economic growth and higher welfare. This implies that there may be a trade-off between short run allocative gains from increased price competition and long run welfare improvements from a higher rate of innovation under a more concentrated structure.

2. There are obviously important policy implications of the relationships between innovation and market structure, on the one hand, and innovation and firm size, on the other. As the role of innovation in promoting competitiveness and growth has become increasingly apparent, a number of policy makers have argued that antitrust laws should be relaxed, or should not be reinforced, as the short run gains from more price competition are offset in the longer term by a slower rate of technological progress. The notion that high market concentration and large firm size are factors conducive to a faster rate of innovation has also been used in the past to justify industrial policies of support for "national champions" through public procurement and R\&D subsidies. The relevance of such views depends on the validity of the hypothesis of a positive effect of market power, concentration or firm size on innovation.

3. This paper is a survey of the large empirical literature on the links between innovation, market structure and firm size. The issue was brought into mainstream economics by Schumpeter, who, writing in 1942, argued that the large firm operating in a concentrated market is the main engine of technological progress. A number of specific hypotheses as to why this may be the case have been advanced, most of which were already present in Schumpeter's own work. The most important among them can be summarised as follows. Innovation increases more than proportionately with firm size because:

1. R\&D projects typically involve large fixed costs, and these can only be covered if sales are sufficiently large.

2. There are scale and scope economies in the production of innovations.

3. Large diversified firms are in a better position to exploit unforeseen innovations.

4. Large firms can undertake many projects at any one time and hence spread the risks of R\&D.

5. Large firms have better access to external finance.

Moreover, innovation is higher in concentrated industries because:

6. Firms with greater market power are better able to finance $R \& D$ from own profits.

7. Firms with greater market power can more easily appropriate the returns from innovation and hence have better incentives to innovate. 
4. Counterarguments have also been suggested. The one which is most frequently invoked is the existence of decreasing returns to scale in the production of innovations due to loss of managerial control and the bureaucratisation of innovative activity. Another argument is that market power based on the absence of strong competitive pressures may lead to inertia.

5. Much of the empirical literature has focused on examining the relationships between innovation, on the one hand, and market power and firm size, on the other, with little emphasis on the specific economic mechanisms involved. The main reason for this is that many of these mechanisms are difficult to examine. The next section of the present study reviews the evidence on whether there is a positive effect of market structure or firm size on innovation. It will be seen that the evidence is inconclusive and that, on the whole, there is little empirical support for Schumpeter's views. It will also be argued, however, that this line of research is subject to methodological problems and that most of these studies do not advance our understanding of the specific mechanisms relating innovation to firm size, market power or market structure.

6. Section 3 of this study reviews the literature on the specific hypotheses as to why market power or firm size may have a positive effect on innovative activity. The central questions here relate to the optimal scale for R\&D or innovation, the role of diversification, appropriability conditions and the role of financial constraints. What is common to all the studies reviewed in this section is the emphasis on mechanisms which involve a one-way direction of causality: from structure to innovative performance. The evidence appears to support some, but not all, of these hypotheses. It seems that small firms face financial constraints to a larger extent than large firms and that the ability to raise finance matters for innovation. On the other hand, there are probably no economies of scale in the production of innovations in most industries, but this has to be balanced against the existence of indivisibilities in R\&D and the fact that $\mathrm{R} \& \mathrm{D}$ projects may involve large fixed costs in some industries. The evidence on the role of diversification and appropriability conditions is inconclusive.

7. On the other hand, it is now widely accepted that the relationship between market structure, firm size and innovation is far more complex than what many studies in this area have hypothesised. The recent theoretical literature has emphasised that both innovation and market structure are endogenous variables and must be seen as simultaneously determined within a system - although the equilibrium outcome in that system, given all the measurable and systematic exogenous factors, is not unique. The literature has also identified a number of specific mechanisms at work. Some empirical evidence on these is now available. Section 4 of this paper surveys a small number of empirical studies that have thrown some light on a number of such mechanisms. Three "themes" will be explored:

1. First mover advantages and disadvantages and their implications for the evolution of market shares and technological leadership.

2. Demand characteristics and their implications for the trade-off between product enhancement and product proliferation and for market structure.

3. Stochastic patterns of firm innovation and growth and their implications for the evolution of market structure over the industry life cycle.

8. One of the key results in the recent literature is that certain characteristics of technology, such as 0the degree of continuity and predictability of technology and the extent of learning economies in innovation, are important determinants of the evolution of technological leadership and the degree of 
turbulence in R\&D-intensive industries. Another key result is that demand characteristics such as the degree of product differentiation affect the extent to which high $R \& D$ intensity will be associated with a high level of market concentration. A third result is that technological events and random differences between firms in innovation and growth play an important role in shaping the evolution of market structure and innovative activity in technologically progressive industries.

9. The recent advances in the study of innovation and market structure have important policy implications. One such implication is that the endogeneity of structure sets a limit to what can be achieved by competition and industrial policies. Nevertheless, there is still a role for policy. The final section of this study attempts to draw some conclusions in the light of the evidence presented both on the "Schumpeterian hypotheses" of the traditional literature and on the "new themes" of the recent literature on market structure and innovation.

\section{Innovation, firm size and market structure}

10. This section critically reviews the empirical literature on the Schumpeterian relationships between innovation and firm size, on the one hand, and innovation and market structure, on the other. Previous surveys include Kamien and Schwartz (1982), Baldwin and Scott (1987), Cohen and Levin (1989) and Cohen (1995).

11. A variety of measures of innovative or technological activity have been used in the literature. They can be classified as measures of either innovative inputs or output. Measures of innovative output include the number of patents, the number of significant innovations, and various indices of the market value of innovations. The most frequently used measures of inputs into the innovation process are R\&D expenditure and personnel involved in R\&D. There are serious problems with all these measures, however (Cohen and Levin 1989). One problem with $R \& D$ expenditure and employment data is that they are subject to errors and biases caused by financial reporting and accounting practices. In addition, some R\&D activity takes place outside a firm's formal R\&D operation. Since many small firms do not have R\&D departments, even though informal $R \& D$ is carried out within the firm, the amount of small firm $R \& D$ may be underestimated in some data sets (see Schmookler 1972, Kleinknecht 1987).

12. Regarding measures of innovative output, the main problems with patent counts are that patents differ greatly in their economic value and that the propensity to patent varies significantly across industries. Attempts to count the number of significant innovations, on the other hand, are subject to some arbitrariness and possible biases in the evaluation procedure; in addition, some innovations are more important than others. It has also been argued that major innovations are often inefficient initially, but undergo a series of small and gradual improvements whose market value is greater than the value of the basic innovation. Four databases of significant innovations have been compiled; three of them were based on technical experts' assessments of the significance of innovations, while the remaining one was constructed by recording innovations reported in the technical and trade press (Acs and Audretsch 1990). Finally, attempts have been made to construct indices of the market value of innovations, such as sales associated with innovations, stock market response to patent grants, patent renewals etc. These variables are clearly imperfect proxies for the actual value of innovations and, in any case, have not been very much used in studies in the Schumpeterian tradition. 


\subsection{Innovation and firm size.}

13. Empirical studies of the relationship between innovation and firm size typically relate some measure of innovative activity to a measure of size, using a cross-section of firms from one or several industries. An assumption implicit or explicit in such analyses is that firm size is exogenous. It is clear, however, that innovation affects firm growth and hence firm size, so that size in year $t$ is influenced by innovative activity in year t-i (Scherer 1992). If, as seems likely, innovative activity is affected by unspecified factors which are serially correlated, firm size is correlated with these factors in year t, so a regression of innovative activity on size will produce biased estimates of the size coefficients. One response to this criticism has been to argue that the effect of innovative activity on firm size occurs with a multi-year lag, so the endogeneity problem is probably not very serious. ${ }^{1}$

14. Another problem with econometric studies of the firm size-innovative activity relationship arises from the need to control for industry effects (Cohen and Levin 1989). Since firm size is likely to be correlated with industry-level variables such as technological opportunity, which are, in turn, likely to have a positive effect on innovation, it is important to control for industry effects to avoid obtaining biased estimates of the size coefficient when using a sample covering many industries. It is, however, difficult to control properly for industry effects, because most large firms are diversified and operate in more than one industries. To avoid this difficulty, industry assignments could be made at a high level of aggregation such as the 2-digit level, but this then introduces measurement error to the extent that relevant industry characteristics vary across industries within a sector.

15. In two early influential studies, Scherer (1965a, 1965b) used a sample of 448 firms from the 500 largest US industrial firms in 1955. He ran regressions of R\&D employment intensity (i.e. R\&D employment relative to total employment) on sales and number of patents on sales both for the whole sample, without including industry effects, and for various sub-samples for particular sectors. He found evidence of an inverted-U relationship between R\&D employment intensity and sales for the pooled sample and for most sub-samples (the chemical sector was an exception, the relationship being clearly positive). He also found that the number of patents increased less than proportionately with sales, except for a few very large firms. These results were interpreted by Scherer as a clear refutation of the Schumpeterian hypothesis of a positive effect of firm size on innovation.

16. Most other studies in the 1960s and 70s also found little support for the Schumpeterian view. Most of this evidence was based on US data, although there was also some evidence for Canada and European countries. Some authors found a positive relationship between R\&D intensity and firm size up to a certain size, and no significant effect for larger firms. Others obtained results similar to those of Scherer or even a negative relationship between R\&D intensity and size (see Kamien and Schwartz 1982 for details on these early studies). However, none of the authors who used cross-industry samples of firms managed to control for industry effects in a satisfactory way. On the other hand, the industry-level studies revealed considerable differences in the tested relationships across industries, although for some industries the evidence was conflicting and the small size of the samples generally resulted in low levels of statistical significance. Despite these limitations, Kamien and Schwartz were able to conclude in their 1982 survey

1. The evidence on the average time between the beginning of a research project and the beginning of the associated revenue stream is somewhat mixed, with estimates ranging from 2 to 4 years. On the other hand, the average time between the completion of a project and an effect on profits is less than a year (see Mansfield et al. 1971, chapters 2, 6 and 8, Pakes and Schankerman 1984). This suggests that the endogeneity problem is more serious in studies which use measures of innovative output than in studies using measures of innovative inputs. 
that, with the exception of the chemical sector, there was little support for the hypothesis of a positive effect of firm size either on R\&D effort or on innovative output.

17. Others were less keen to totally dismiss Schumpeter, however. Soete (1979), using US data for some 500 firms in 1975 and 1976, found that R\&D intensity increased with size in a number of sectors, although this was not always true for the largest firms, and decreased with size in others. Soete also found a positive relationship for the pooled sample, but, since he failed to control for industry effects, this result may not be very reliable. Both Freeman (1982) and Rothwell and Zegveld (1982) have drawn attention to Schmookler's (1966) view that larger US firms have a lower propensity to patent their innovations than smaller ones, and suggested that this may partly explain why small US firms account for a number of patents which is disproportionate to their size and even to their R\&D expenditure. The same authors pointed out that much of the empirical work on innovation and firm size had focused on firms which engaged in formal R\&D and were relatively large. Small firms with less than 100 employees, on the other hand, typically do not perform any formal R\&D and, at least in the UK, have produced a less than proportionate number of innovations since 1945, which seems to be in line with the Schumpeterian hypothesis. It was acknowledged, however, that once the vast majority of firms that perform no formal $R \& D$ are excluded from the analysis, the size-R\&D relationship is weak, non existent or even negative.

18. Several analyses of the effect of firm size on innovation output have used the four databases of significant innovations compiled in the 1970s and 80s. Two such databases were compiled by Gellman Research Associates, a US private firm. The first included 500 innovations judged by experts to be the most important innovations introduced in five major industrial countries between 1953 and 1973; the second contained 635 innovations introduced in the US between 1953 and 1979. The other two databases are much larger and have been more extensively studied. The first was constructed at the Science Policy Research Unit at the University of Sussex and includes 4378 significant innovations, as identified by industry experts, commercialised in the UK between 1945 and 1983. The second was compiled by the Futures Group, a US private firm, for the US Small Business Administration, and records 8074 innovations introduced in the US in 1982 and reported in the technical and trade press. Acs and Audretsch (1990) have compared these 4 databases and have found them similar with respect to the distribution of innovations between large and small firms and across industries.

19. Two aspects of the Gellman Research Associates' first report (1976) were of particular interest. The first was an international comparison of the distributions of 352 innovations by firm size. The second was an analysis of the relationship between firm size and the radicality of innovations in each country. The percentages of innovations made by small or medium-sized firms, i.e. firms with sales at the time of less than $\$ 50$ million, were 57\% for France, 50\% for the US, 37\% for West Germany, 33\% for the UK and $20 \%$ for Japan. In addition, there was evidence that small and large US firms outperformed medium-sized US firms as producers of radical innovations (the samples for the other countries were too small for this comparison to be meaningful). Some caution is needed with these results, however, because the crosscountry variation probably reflects differences in the industrial structure of these countries and also because the samples for the countries other than the US were small.

20. Pavitt et al. (1987) have examined the relationship between firm size and innovative output using the SPRU database. The broad picture they present offers little support for the Schumpeterian hypothesis of a positive effect of size on innovation. Their main results can be summarised as follows. ${ }^{2}$

2. Earlier results from partial datasets are discussed in Freeman (1982) and Rothwell and Zegveld (1982). 
1. A comparison of innovative intensities by firm size category for various time periods was made by dividing the share of innovations of each firm size category in any particular time period by the share of employment of all UK firms falling in this category during the specified time period. Innovation intensity was shown to be, on the whole, greater for large firms (more than 10000 employees) and small firms (between 100 and 2000 employees) and smaller for medium-sized and very small firms. In the 1976-1980 period, for instance, innovative intensities for the various size categories were as follows:

\begin{tabular}{lc} 
UK employment & Innovative intensity \\
\hline $1-99$ & 0.59 \\
$100-199$ & 1.19 \\
$200-499$ & 1.49 \\
$500-999$ & 1.00 \\
$1000-1999$ & 0.82 \\
$2000-4999$ & 0.65 \\
$5000-9999$ & 0.45 \\
$10000-19999$ & \multicolumn{2}{c}{1.22} \\
$20000-49999$ & 1.00 \\
$50000+$ & 1.90
\end{tabular}

2. Over the 1956-1983 period, innovation intensity increased steadily for firms with less than 500 employees and declined for firms with more than 500 and less than 10000 employees. Hence, small firms were important innovators, and increasingly so. For example, during the 1960s innovative intensity was highest in the 1000-1999 and 50000+ size classes, while in the late 1970s and early 80s it was highest in the 100-199, 200-499 and 50000+ size classes. It should also be noted that, as these numbers suggest, the very largest firms were consistently the best performers throughout the 1956-1983 period.

3. There were important sectoral differences. For instance, smaller firms were important innovators in machinery, instruments and construction, larger firms in food products, chemicals, metals, electrical engineering and aerospace. These differences probably reflected sector-specific characteristics other than technological opportunity, since both machinery and instruments, on the one hand, and chemicals and electrical engineering, on the other, are sectors of high technological opportunity. Pavitt et al. suggested that the sectoral differences were related to appropriability conditions and the scope for diversification. In chemicals and electrical engineering, firms typically produce innovations across a range of technologically related 3-digit industries within their principal 2-digit sector and, in addition, technological imitation by firms producing outside these sectors is difficult. In mechanical engineering and instruments on the other hand, firms are much more specialised technologically within their principal 3-digit industry and imitation by firms producing outside these sectors is relatively easy. These ideas should be seen in conjunction with earlier hypotheses advanced by Pavitt (1984) linking the scope for diversification and the typical size of innovating firms to technology and demand characteristics such as the extent to which innovative activity is science-based or driven by customer requirements, and the extent to which appropriability is facilitated by the existence of large fixed costs and significant learning economies. Clearly, in trying to explain the observed sectoral differences in the size of innovating firms by reference to primary factors such as technology and demand, the studies by Pavitt (1984) and Pavitt et al. (1987) have identified a number of important elements for a theory of market structure in R\&D-intensive industries. 
21. The US Small Business Administration database has been studied by Acs and Audretsch (1987, 1990). A simple comparison of average innovative intensities, i.e. the number of innovations divided by the number of employees, of larger firms (more than 500 employees) and smaller firms (less than 500 employees) suggested a negative relationship between firm size and innovative activity. It was also found that smaller firms were more innovative in 156 industries, larger firms in 122 industries, while innovative intensity was zero both for large and small firms in 170 industries. Acs and Audretsch have interpreted these results as evidence that the whole debate regarding which firm size is more conducive to innovation is pointless and the real issue is which industry characteristics favour either large or small innovators. They examined this question by regressing the difference between large firm innovation intensity and small firm innovation intensity at the 4-digit industry level (excluding industries with zero innovation intensity) on a number of industry characteristics. Few of the coefficients were significant, however, even at the $10 \%$ level. In any case, it is difficult to interpret the results due to the inclusion of a large number of endogenous variables among the regressors.

22. In a later study, Acs and Audretsch (1991) matched their data set of innovations with data on firm size for 732 relatively large firms. Of those firms, 426 had not produced any innovations, while 306 had at least one innovation. Using innovation counts as the dependent variable and including in the model either fixed effects or R\&D intensities at the sector level for 14 sectors, Acs and Audretsch found that innovations increased less than proportionately with firm size. They obtained the same result even when the sector-specific variables were dropped from the regression, and, interestingly, independent of whether the non innovating firms were included or excluded. Finally, they estimated the model separately for each of a number of sectors and found that innovations increased less than proportionately with firm size in every sector, except, in some sectors, for the largest one or two firms, which had produced a more than proportionate number of innovations.

23. Many studies of the firm size-R\&D intensity relationship in the 1980s have exploited new and better data sets and have applied more sophisticated econometric techniques. Using a more comprehensive sample of relatively large US firms than any previously employed (2582 firms, of which only 1479 reported R\&D and only 1754 had been granted at least one patent during the 1965-1979 period), Bound et al. (1984) found a U relationship: R\&D intensity first decreased and then increased with size, i.e. both small and large firms were more R\&D-intensive than medium-sized firms. These authors also investigated the important question of whether the fact that many firms do not report R\&D will bias results based only on firms which do. Their results from OLS regressions excluding non reporting firms were not much different from results when the whole sample was used and non linear econometric techniques were applied in an attempt to correct for possible selectivity bias. This is encouraging, as much of the literature on R\&D and firm size has paid little attention to the implications of using samples which either include or exclude firms with zero R\&D.

24. A number of studies have used data at the business unit level from the US Federal Trade Commission Line of Business Program of the mid-1970s. Since large firms are typically diversified, with business units in several industries, this data set had two advantages. First, it was possible to control properly for industry effects. Second, the effects on R\&D intensity of both business unit size and firm size could be examined. In fact, while some of the arguments advanced to justify the hypothesis of a positive effect of firm size on innovative activity refer to the overall size of the firm (e.g. better access to external finance), others refer to the business unit (e.g. fixed R\&D costs), so this was an opportunity to examine the validity of some of these arguments. A potential shortcoming of the FTC data set was that only relatively large firms were covered.

25. Scherer (1984, chapter 11) used the FTC Line of Business data to examine the effect of business unit size on business unit R\&D intensity. Despite the fact that for many industries there were only a few 
observations, Scherer ran simple regressions of R\&D expenditure on sales for 196 industries. R\&D intensity increased with sales in $20.4 \%$ of the industries and decreased with sales in $8.2 \%$ of the industries. In all the remaining cases the size coefficient was not statistically significant (it was positive in roughly half of the cases). Scherer also ran regressions with patent counts as the dependent variable. The number of patents was found to increase more than proportionately with sales in $11.3 \%$ of the industries, less than proportionately in $15.3 \%$ of the industries, while in the remaining cases no statistically significant departure from proportionality was detected (in slightly more than half of these cases the number of patents increased less than proportionately). Hence the general picture was one of little overall effect of size on innovative activity.

26. Cohen et al. (1987) also used the FTC data. They ran OLS regressions of R\&D intensity on both firm and business unit size for a sub-sample of R\&D performing business units, using either fixed effects or variables related to appropriability conditions and technological opportunity to control for industry characteristics. Recognising the possibility of selectivity bias in samples excluding business units not engaged in R\&D, they also analysed the whole sample using Tobit techniques. On the whole, neither size variable had a statistically significant effect on R\&D intensity when a very small number of outliers, namely seven very large firms with very high reported R\&D intensity relative to their size, were removed. Appropriability and technological opportunity at the industry level explained much of the variance in R\&D intensity between firms. On the other hand, a threshold effect was identified, using a probit model to explain the decision of the business unit to do R\&D: the size of the business unit, but not the overall size of the firm, had a positive and significant effect on the probability of conducting R\&D. Finally, the authors also found that the exclusion of business units not engaged in R\&D resulted in a modest upward bias in the (typically insignificant) firm size coefficient, i.e. the effect of firm size on R\&D intensity was overstated in the OLS regressions. However, since the qualitative results were identical in the two specifications, Cohen et al. concluded that selectivity bias is probably not a major problem in studies of the firm size-R\&D intensity relationship.

27. Cohen and Klepper (1994) extended this analysis of firm versus business unit size effects on R\&D. They regressed business unit R\&D separately on firm and business unit size. Firm size alone explained an average of $15 \%$ of the variance in business unit $R \& D$, and the coefficient on firm size was usually not significant. Business unit size alone explained an average of $65 \%$ of the variance in business unit R\&D and the coefficient on business unit size was typically positive and significant. These findings suggest that any positive relationship between $R \& D$ and firm size is mainly driven by factors which are relevant at the business unit rather than at the firm level. The Cohen and Klepper (1994) results are consistent with earlier findings by Lunn and Martin (1986). Working with the FTC Line of Business data, these authors regressed R\&D intensity on business unit size, concentration and other variables, using only a single dummy, however, to control for "high" versus "low" technological opportunity, and found a positive and statistically significant impact of business unit size on R\&D intensity.

28. Finally, Patel and Pavitt (1992) examined the relationships between firm size and R\&D expenditure, on the one hand, and firm size and number of US patents, on the other, for the world's 660 largest, technologically active, manufacturing firms divided into 16 sectors. They found that in 13 sectors increases in $R \& D$ expenditure with firm size were not significantly different from proportional, while in the remaining 3 sectors (chemicals, mining and motor vehicles) they were more than proportional. Increases in US patenting with firm size were not significantly different from proportional in 11 sectors, more than proportional in 4 sectors (mining, electrical and electronic products, materials and food) and less than proportional in one sector (pharmaceuticals).

29. What is then the consensus, if any, on the relationship between firm size and innovative activity? First, the large majority of very small firms do not engage in $R \& D$, although the extent to which some 
small firms do informal R\&D is difficult to assess. Second, above a certain threshold firm size, R\&D seems to rise more or less proportionally, on the whole, with firm size, although there are variations of this pattern across industries, time periods and countries. Third, the evidence on the relationship between innovative output and size is inconclusive; most authors would probably agree that innovative output tends to rise less than proportionately with firm size, although other patterns have also been suggested for particular industries, periods or countries. Fourth, smaller firms seem to produce more innovations or obtain more patents relative to their formal R\&D spending than larger firms.

30. The studies reviewed in this section are subject to a number of limitations, some of which have already been mentioned: problems with measuring innovative activity, the potential endogeneity of firm size, the difficulty to control properly for industry effects, and the undereporting of R\&D by small firms. Cohen and Levin (1989) also argue that the literature, with a few exceptions, has paid little attention to the need to control for firm specific characteristics other than size, and to the effects of possible selectivity bias when using samples of R\&D performing firms.

31. Apart from these problems, which mainly relate to measurement and econometric methodology, there are more fundamental limitations. First, little has been learned from most of these studies as to the specific mechanisms, such as scale economies, financial constraints, appropriability conditions etc, that presumably relate innovation to firm size. Second, no account has been taken of the fact that both firm size and innovation are in fact endogenously determined within a complex system where technological opportunity, strategic interaction, the characteristics of demand, and even chance play an important role. Third, since it is now apparent that the firm size-innovative activity relationship tends to vary considerably across industries, it may be more useful to focus on particular factors that influence innovation, firm size and the interaction between the two, rather than trying to establish a global pattern which may not exist. This is not to suggest that the literature reviewed in this section has not been useful in establishing that, at least for firms above a moderate size threshold, there is probably no general advantage related to size. This is a first important step towards a better understanding of the specific ways in which firm size and innovation are related.

\subsection{Innovation and market structure}

32. We now turn to the literature examining the relationship between innovation and market structure. Many studies in this area have used single equation models to relate some measure of innovative inputs or output to some concentration index. A serious problem with this approach is the obvious endogeneity of concentration. It has long been argued that the relationship between market structure and innovation is not a simple one way causal relationship, because market structure is affected by innovative activity. More generally, both variables are endogenously determined within a complex system of interactions with numerous other variables. Recognising the problem, some authors have used instrumental variables for concentration in the context of single equation models, while others have estimated simultaneous equation systems in which both innovation and market structure are treated as endogenous.

33. A second difficulty arises with respect to industry-specific characteristics which may be correlated with concentration and may also affect innovation. A number of studies have controlled for technological opportunity, appropriability conditions, or both. However, while technological opportunity can be treated as exogenous, it is questionable whether the same can be said for appropriability. One of the arguments most frequently put forward to rationalise the hypothesis of a positive effect of market power on innovative activity is that firms with market power can more easily appropriate the returns from their innovations. Suppose now that the inclusion of a measure of appropriability among the explanatory 
variables in a regression of innovative activity on concentration reduces substantially the coefficient and the t-statistic on concentration. It would be hard to interpret such a result. For instance, this might indicate that market power matters for innovation and the effect works through appropriability rather than the ability to finance R\&D. Alternatively, it might indicate that concentration does not matter, as a correlation between concentration and appropriability does not necessarily imply a causal relationship between these variables.

34. A final problem arises from the fact that while the Schumpeterian hypothesis is that innovation is higher in the presence of market power, most of the literature has actually tested a different proposition, namely that innovation is higher in concentrated markets. The implicit assumption is that market power, i.e. the profit margin or mark-up, is greater in concentrated markets. This is not obvious in a framework where market structure is seen as endogenous. For example, there is evidence which supports the view that more intensive competition can result in higher concentration levels, as margins are squeezed and firms cannot cover their fixed costs unless their number falls through merger or exit (Sutton 1991, Symeonidis 1995). These recent results and the inconclusiveness of the vast empirical literature on the relationship between profitability and market structure (Schmalensee 1989) suggest that concentration is at best an imperfect proxy for market power in cross-industry studies.

35. Early studies of the innovation-market structure relationship produced mixed results. Scherer (1965b) was the first researcher who tried to control, though somewhat crudely, for technological opportunity in his analysis of the effect of concentration on the number of patents for a sample of 48 industries, mainly from the chemical, mechanical engineering and electrical engineering sectors. Including just two dummy variables to capture sector-specific technological opportunity, he found that the effect of concentration on patents was not statistically significant. In a subsequent study, Scherer (1967) used various indices of $R \& D$ employment intensity as the dependent variable and again included a small number of sector dummy variables to control for differences in technological opportunity among the 56 industries in his sample. The results were somewhat sensitive to econometric specification, but, on the whole, they were seen by Scherer as providing some support for the Schumpeterian hypothesis: the coefficient on concentration was positive and statistically significant in some regressions, and positive but not significant in others, although there was some weak evidence that the relationship tended to break down at higher levels of concentration. ${ }^{3}$ The most persistent result was the sharp fall in the incremental explanatory power of concentration when sector dummy variables were included among the regressors.

36. A number of other studies using single-equation models also found evidence of a positive relationship between concentration and research intensity. On the other hand, many authors failed to provide any support for the Schumpeterian hypothesis. The studies covered a number of countries, namely the US, Canada, the UK, France and Belgium (see Kamien and Schwartz 1982 for a review). On the whole, support for Schumpeter's thesis seemed to be weaker when the number of patents rather than R\&D intensity was used as the dependent variable. Many studies have attempted to analyse whether the R\&Dconcentration relationship depends on other industry-level variables. For example, Comanor (1967) found a positive relationship in industries with low advertising intensity and no relationship in industries with high advertising intensity. Shrieves (1978) found a positive relationship in consumer nondurable and producer goods industries and no relationship in consumer durable goods industries. The theoretical arguments used to rationalise such results were not very convincing.

3. In only one out of four regressions including the square of the concentration index was the coefficient on this variable significant at the 5\% level, although it was always negative, suggesting an inverted-U relationship, with maximum R\&D employment intensity occuring at 4-firm concentration ratios in the range of $50 \%$ to $65 \%$. 
37. Some more recent studies have used the US Federal Trade Comission Line of Business data to analyse the effect of concentration on R\&D intensity. Scott (1984) used data at the business unit level (for 3388 business units). On the other hand, Levin et al. (1985) and Scherer (1983a) used FTC data at the industry level. Scherer found a positive and statistically significant effect of concentration on R\&D intensity in a regression with 7 dummies intended to control for technology class. When the regression was estimated separately for each technology class, a positive and significant effect emerged in two classes only, namely the mechanical and "traditional" sectors. Both Scott and Levin et al. found an inverted-U relationship between $R \& D$ intensity and concentration, with a peak at a 4-firm concentration ratio of around $50 \%$ to $65 \%$, when not controlling for industry characteristics. In addition, Levin et al. found a similar inverted-U relationship between a measure of innovative output, constructed on the basis of data from a survey of $R \& D$ executives in 130 industries, and concentration. However, the inclusion of fixed sector and firm effects in Scott's regressions rendered statistically insignificant the coefficients on concentration and its square. Similarly, Levin et al., who used two-stage least squares in an attempt to control for the endogeneity of concentration, found that while the inverted-U relationship persisted when dummy variables at the sector level were introduced, it clearly broke down in the R\&D equation when a set of variables intended to capture inter-industry differences in appropriability and technological opportunity were included among the regressors. In the innovative output equation, the inclusion of appropriability and technological opportunity variables resulted in a positive and significant at the $10 \%$ level coefficient on concentration and an insignificant coefficient on its square. Unfortunately, the simultaneous inclusion of concentration, appropriability and technological opportunity indices makes these results difficult to interpret, because one of the main arguments put forward to justify the presumed positive effect of market power on innovative activity relates precisely to the impact of market power on appropriability conditions.

38. An issue which has seldom been addressed in the literature on market structure and innovation is the possibility of systematic biases in the measurement of the main variables of interest. Kleinknecht and Verspagen (1989) have suggested that informal R\&D by small firms in the Netherlands is significantly underestimated in the official statistics and that when this is taken into account the positive effect of concentration on R\&D employment intensity disappears. With respect to market structure, it may be argued that biases result from the fact that concentration is not measured at the right level of aggregation, and that a positive effect on innovation could perhaps be identified if the 3-digit or 4-digit industries typically used in the literature were split into sub-industries corresponding to well defined markets. This point will be further discussed in section 4 of this paper. ${ }^{4}$

4. Kleinknecht and Verspagen (1989) have regressed R\&D employment intensity on concentration, first for 41 industry groups and then at a finer level of aggregation, using 63 industry groups. While the coefficient on concentration was not significant in the former regression, it was significant at the $10 \%$ level in the latter, thus providing weak evidence of a positive relationship between concentration and $\mathrm{R} \& \mathrm{D}$ employment intensity. An obvious objection here is that even this finer level of aggregation is quite high, so this result is not relevant for the argument that failure to measure concentration at the appropriate level of aggregation may result in a bias. In Kraft's (1989) study of the determinants of innovation in 57 German firms in the basic metals, mechanical engineering and metal goods sectors, the measure of market structure used is the number of main competitors in the major markets in which any given firm operates. This variable has a positive and significant effect on

5. innovative output (measured as the percentage of sales attributed to products developed during the last five years). It is an open question whether this result has anything to do with the fact that market structure is measured at an apparently appropriate aggregation level, or with the absence of controls for technological opportunity, or with some third factor. 
39. One study which explicitly recognised that market power cannot be fully captured by just one variable, namely concentration, is the study by Geroski (1990). He used six different measures of market power in his analysis of the effect of market power on the number of innovations in 73 3-digit industries in the UK: the extent of market penetration by entrants, the market share of imports, the relative number of small firms, the within period percentage change in concentration, the market share of exiting firms and, finally, the concentration ratio. His dependent variable is the number of significant innovations introduced in the UK during 1970-1979 as recorded in the SPRU database, split into two cross-section samples, for 1970-74 and 1975-79 respectively. Geroski made a distinction between a "direct" and an "indirect" effect of market power on innovation. The latter, if it exists, mainly works through the presumed ability of firms with market power to appropriate more easily the returns to innovation. The former captures everything else, including material advantages such as availability of internal finance and behavioural disadvantages such as bureaucratic inertia, so it can be positive or negative. In an attempt to distinguish the two effects, Geroski included among the regressors a proxy for expected profitability. He estimated the model using both ordinary least squares and two-stage least squares, even though there was little evidence of endogeneity of the market power variables. When fixed industry effects were not included, the coefficient on the expected profitability proxy was positive and significant, while the coefficient on concentration was positive but insignificant. However, when fixed industry effects were introduced to control for technological opportunity, the coefficient on the expected profitability proxy was positive but insignificant, while the coefficient on concentration was negative and significant (the effect of the other market power variables was in the same direction but smaller and, on the whole, not significant). Geroski concluded that although the indirect effect was positive, the direct effect was negative and dominant, so that the overall effect of market power on innovation was negative. A problem with this study, however, is the interpretation of the expected profitability proxy, as this clearly reflects current profits, which in turn are relevant for the "direct" effect of market power on innovation. Consequently, the interpretation of the market power variables is also somewhat uncertain.

40. While most of the literature has focused on the impact of market structure on innovative activity, some studies have explored the possibility that causality might run in the opposite direction as well. Innovation may affect market structure because $R \& D$ involves fixed costs, or by affecting the pattern of firm growth in an industry. Innovation can also affect market structure indirectly, by increasing or decreasing the minimum efficient scale of production. The seminal study in this area is a detailed case study of the evolution of the US commercial aircraft market during 1932-1965 (Phillips 1971). Advances in technology which often arose outside the industry provided opportunities and incentives for manufacturers to develop new types of aircraft. The stream of innovations resulted in a rise in concentration as "success bred success" and R\&D expenditures increased. Some of these themes will be taken up in section 4 of the present study. We confine ourselves here to a discussion of econometric studies which have analysed the relationship between innovative activity and market structure in the context of simultaneous equation models.

41. Analyses of this type have not been any more conclusive than single-equation studies. The models typically consist of two or more equations and both innovative activity and concentration are treated as endogenous. Often the system includes an equation for advertising as well. Results from these studies have been mixed. For example, Farber (1981) estimated a 3-equation system with concentration, R\&D employment intensity and advertising intensity as the endogenous variables, using a sample of 50 4digit US industries. He found that concentration had a negative impact on R\&D intensity at small levels of buyer concentration, and a positive impact at medium or high levels of buyer concentration. ${ }^{5}$ Lunn (1986)

6. Farber's interpretation of these results was based on the explicit assumption that the lower the level of buyer concentration the higher the degree of appropriability, as well as on a number of implicit assumptions, namely that the positive impact of market power on innovation works mainly through 
used the number of patents as his measure of innovative activity and was therefore able to make a distinction between process and product innovation. He estimated a 4-equation system for 191 US industries and found a positive and statistically significant effect of concentration on process innovation and no effect on product innovation. Moreover, the coefficient on process innovation in the concentration equation was positive and significant at the $1 \%$ level, while the coefficient on product innovation in the same equation was negative and significant only at the $10 \%$ level. These were interesting results, although the theoretical arguments advanced by Lunn to rationalise them were not very strong. A possible interpretation of the differential impact of process and product innovation on market structure will be suggested in section 4 of the present study.

42. Despite the fact that they provide a richer analysis of the interaction between market structure and innovation, most simultaneous equation studies use rather ad hoc empirical models and do not significantly improve our understanding of the specific mechanisms relating market structure and innovative activity. Exceptions are two studies by Levin and Reiss (1984, 1988), which involved estimating empirical models loosely based on the theoretical oligopoly model of Dasgupta and Stiglitz (1980). Levin and Reiss (1988) constructed a three-equation system to analyse the impact on concentration, process R\&D intensity and product R\&D intensity of exogenous demand and cost parameters such as the price elasticity of demand, technological opportunity and appropriability. However, concentration was not included in the R\&D equations. In Levin and Reiss (1984), the endogenous variables were concentration, $R \& D$ intensity and advertising intensity and the key parameters of interest were the price elasticity of demand, the effectiveness of advertising, technological opportunity and appropriability. The coefficient of concentration in the R\&D equation was negative and statistically significant, but it should be noted that the data used for this study were at a very high level of aggregation (20 industry groups for three different years over a 10-year period).

43. While the main body of the literature on the innovation-market power relationship has simply used concentration as a proxy for market power, a small number of recent studies have instead focused on the impact on innovation of changes in the international environment faced by innovating firms. In particular, these studies have examined how domestic innovators respond to increased import competition, which presumably erodes their market power. The results were, once again, mixed. Scherer and Huh (1992) analysed the R\&D spending reactions of 308 US firms to increased high-technology import competition over 1971-1987. They found that most of the variation in company R\&D intensity change was unsystematic and that rising import competition had a negative but statistically insignificant effect on R\&D intensity in the short run. The inclusion of the profit margin among the explanatory variables in their regressions, however, makes the results somewhat difficult to interpret. Bertschek (1995), on the other hand, found a positive and statistically significant effect of the 2-digit industry import penetration ratio on the production of both product and process innovations for 1270 German firms over 1984-1988. While this line of research seems promising, a problem with these studies is that they have used rather ad hoc specifications and have tended to focus on the short run. The analysis of long run effects would require not only data over a long period, but also a different econometric specification, as some of the variables often included in short run empirical models are endogenous in the longer term.

appropriability conditions, that there are also disadvantages of market power for innovation, and that appropriability is necessary for innovative activity. Hence if appropriability can be ensured without a high degree of seller market power (for instance by a low level of buyer market power), then the disadvantages of seller market power for innovation dominate and produce a negative relationship. But if appropriability is not ensured otherwise, then market power is necessary for innovation and a positive relationship follows. This interpretation relies on many assumptions, however, and one should also keep in mind the rather small size of the sample. 
44. The main characteristic of the empirical literature on the innovation-market structure hypothesis is its inconclusiveness. However, three main results seem to have emerged. First, there is little evidence of a positive relationship between R\&D intensity and concentration in general, although there may be circumstances where such a relationship exists. Second, there is even less evidence of a positive relationship between innovative output and market structure. Third, industry characteristics such as technological opportunity explain much more of the variance in $R \& D$ intensity or innovation than market structure.

45. This literature is also subject to serious limitations. These include measurement problems that may result in systematic biases, econometric problems relating to the endogeneity of market structure, as well as methodological problems such as the use of concentration as a proxy for market power. There are also more fundamental limitations. With the exception of very few studies (e.g. Levin et al. 1985, Geroski 1990), the literature has not attempted to examine the specific hypotheses as to why a positive, or negative, effect of market power on innovation may exist. Moreover, it has failed to take into account the fact that market structure, market power and innovation are all endogenously determined within an equilibrium system where the main exogenous factors are technology, the characteristics of demand, the institutional framework and possibly chance. On the other hand, the literature does suggest that market power is not, in general, necessary for technological progress, although sometimes it may be. The next step is to try to identify some of the precise mechanisms relating market structure, market power and innovation. Only then can the role of competition and industrial policies be fully defined.

\section{Specific mechanisms in the Schumpeterian tradition}

46. A variety of arguments have been advanced in support of the hypothesis that innovative activity is favoured by high concentration and large firm size. Many counterarguments have also been suggested (see Kamien and Schwartz 1982, Rothwell and Zegveld 1982 for comprehensive discussions). Some of these involve behavioural characteristics and are hard to test in general, so only circumstantial evidence on their validity may be available. An example is the notion that market power caused by the absence of competitive pressures may lead to inertia and hence to lower innovative activity. Others can be more easily tested, although in some cases the evidence is open to various interpretations. This section will review the empirical literature on the most important hypotheses as to why firm size or market power may have a positive effect on innovative activity. In particular, it has been argued that innovation increases more than proportionately with firm size because:

1. R\&D projects typically involve large fixed costs, and these can only be covered if sales are sufficiently large.

2. There are economies of scale and scope in the production of innovations.

3. Large diversified firms are in a better position to exploit unforseen innovations.

4. Large firms can undertake many projects at any one time and hence spread the risks of R\&D.

5. Large firms have better access to external finance.

In addition, innovative activity may be higher in concentrated industries because:

6. Firms with greater market power are better able to finance $R \& D$ from own profits. 
7. Firms with greater market power can more easily appropriate the returns from innovation and hence have better incentives to innovate.

What all these mechanisms have in common is the fact that they involve a one-way causality, from market structure to innovative activity.

\subsection{The cost of $R \& D$}

47. According to one view, R\&D projects typically involve large fixed costs, i.e. costs which are independent of the size of the market for the innovation. The disadvantage of small firms stems from the fact that, given the gross rate of return, their expected sales are not sufficiently large to allow them to cover these costs. Note the two implicit assumptions in this line of reasoning: the first is that firms mainly exploit their innovations through their own output, the second is that current firm size limits firm growth (Cohen and Klepper 1994). There is, in fact, empirical evidence which supports these assumptions (see Cohen 1995). The question then is whether it is actually the case that the costs of $R \& D$ projects are typically large. Another question is to what extent relatively large R\&D projects can be jointly carried out so that the costs are spread among a number of smaller firms.

48. There is hardly any systematic evidence on the costs of $R \& D$ projects across industries. Case study evidence suggests that in some industries, such as aircraft, the cost of a project may be so large that even large firms find it difficult to conduct independent $\mathrm{R} \& \mathrm{D}$, while in other industries, such as instruments, $R \& D$ costs are relatively small (in fact, the instrument engineering sector is the typical example of a sector with high R\&D intensity and low levels of concentration). There may also be important variations from one project to another within the same industry. For example, in a very detailed case study of one large firm in the ethical drug industry, Mansfield et al. (1971, chapter 4) found that the average cost per R\&D project varied significantly across categories of ethical drugs: for new chemical entities it was $\$ 534,000$, for compounded products it was $\$ 161,000$ and for alternate dosage forms it was $\$ 83,000$. Finally, it is often the case that after the introduction of a major innovation many minor improvements are made, and these may have a greater market value than the initial innovation. The evidence then implies that the notion of a typical cost of $R \& D$ is probably meaningless.

49. There is also little systematic evidence on the evolution of R\&D costs. Scherer (1991) has estimated that the average cost of significant innovations in the US has risen at about $1 \%$ per year between 1969 and 1986, while the overall mean during this period was \$1.35 million per innovation in 1982 dollars. However, in some industries, such as aircraft and pharmaceuticals, the increase in R\&D costs has been much higher. According to Mowery and Rosenberg (1989, chapter 8), the same is true for information technology industries.

50. It may also be asked whether, in industries where the cost of $\mathrm{R} \& \mathrm{D}$ projects is high, the disadvantage of small firm size can be overcome through cooperative R\&D agreements allowing for the spreading of R\&D costs among a number of smaller firms. This issue has not been systematically examined in the literature on cooperative R\&D. It is possible to think of reasons why joint small firm $R \& D$ may not be a substitute for large firm $R \& D$; for instance, management of cooperative agreements may be difficult. It should also be mentioned that there is some rather scant evidence that the propensity to participate in $R \& D$ agreements or the fraction of joint $R \& D$ to total $R \& D$ at the firm level may be positively related to firm size. Colombo (1995) has analysed R\&D agreements, broadly defined (i.e. including technology transfer and licencing agreements, as well as joint R\&D), of 100 relatively large firms in the semiconductor, data processing and telecommunications industries over 1981-1986, and has found that large firms had a higher propensity to participate in R\&D agreements than their smaller rivals, 
other things being equal. Note that information technology was the largest field of technology alliances during the 1980s, accounting for around $40 \%$ of the total number of technology alliances over that period (Hagedoorn and Schakenraad 1993). Also, Link and Bauer (1989) have found, using a sample of 92 large US firms from various sectors, 62 of which were engaged in joint R\&D, that weighted market share had a positive and statistically significant effect on the fraction of joint $R \& D$ to total $R \& D$ at the firm level in a Tobit regression also including the weighted 2-digit industry concentration ratio, the profit margin and the import penetration ratio. A limitation of both these studies is the fact that they have used small samples of relatively large firms. There are, on the other hand, a few studies which suggest that a considerable fraction of small R\&D intensive firms are engaged in joint R\&D (see Dogson 1993, chapter 11), although often this involves cooperation with large firms rather than other small firms. ${ }^{6}$

51. In conclusion, there are large differences in the cost of $R \& D$ projects across industries and possibly also within the same industry. It might be misleading to conclude that when these costs are high, large firms have an advantage in innovation, since firm size and market structure should be seen as endogenous: when the cost per R\&D project is high, we simply expect innovative firms to be large, other things being equal. ${ }^{7}$ There is hardly any direct evidence on the extent to which the disadvantages of small firm size in industries with costly $R \& D$ projects can be overcome through joint $R \& D$.

\subsection{Economies of scale and scope in the production of innovations}

52. A number of studies have focused on the relationship between innovative input, output and firm size in an attempt to investigate the existence of scale and scope economies in the production of innovations. There are, in fact, two types of studies in this area: on the one hand, those that examine the relationship between the "productivity" of R\&D (i.e. the ratio of innovative output to $R \& D$ expenditure or employment) and firm size; on the other, those that analyse the relationship between the productivity of $R \& D$ and $R \& D$ expenditure or employment, or simply between innovative output and inputs. The expression "scale economies" may be somewhat misleading here, because the main issue is not whether innovation increases more or less than proportionately with $R \& D$ for a given firm size; it is rather whether the ratio of innovations to $R \& D$ increases or decreases with firm size.

53. Various arguments have been proposed to support the hypothesis of economies of scale and scope in the production of innovations. These include the existence of positive spillovers between the various research projects within a firm, and the positive effect on researchers' productivity of the interaction and complementarities within a large team. Counterarguments have also been suggested. These usually refer to various organisational problems related with size, such as the loss of managerial control and the bureaucratisation of innovative activity.

7. In fact, most of the literature on small firm cooperative $R \& D$ has focused on large firm-small firm linkages. More generally, some authors have argued that the pattern towards increased R\&D cooperation among firms, including cooperation between large and small firms, has minimised the relevance of the whole debate on the relationship between firm size and innovation. These authors emphasise the existence of complementarities in R\&D between firms of different sizes (see, for example, Teece 1992, Rothwell 1989).

8. Note that the cost of an $R \& D$ project in a given industry is itself partly endogenous, since it is affected by the past, and possibly also the current, strategic choices of the firms. It is probably correct to assume, however, that at any given point in time this cost cannot be lower than a certain minimum level, which is taken as exogenous by the firms. 
54. This literature is subject to serious practical problems of measurement of innovative inputs and output. A number of authors seem to agree that much of the R\&D of small firms is informal and goes unreported in the statistics. It has also been argued that large firms may have a lower propensity to patent their inventions than small firms. Finally, the nature of innovative activity may be different in large and small firms (for example, some of the research of large firms is basic research), so the respective rates of return on R\&D may not be directly comparable. ${ }^{8}$

55. Most of the early studies have found no evidence of economies of scale in the production of innovations, and some have even found evidence of diseconomies of scale. Scherer (1965b), using a sample of 352 firms from the 500 largest US industrial firms in 1955, regressed patent counts on R\&D employment and found a linear relationship. When he regressed patents per unit of sales to R\&D employment per unit of sales, however, he found evidence of decreasing returns. Schmookler (1972) compared the ratio of $R \& D$ expenditure to patents (i.e. the inverse of $R \& D$ productivity) by firm size category in six industrial sectors, namely machinery, chemicals, electrical equipment, petroleum, instruments, and all other industries, using 1953 US data. Only firms with R\&D programs were included in the study and three different size classes were defined. In all six sectors, this ratio was far bigger for firms with more than 5000 employees than for firms with less than 1000 employees, while the picture for firms of intermediate size was somewhat mixed (in 4 sectors they had an even smaller ratio than small firms). The unweighted average ratio for all sectors was $\$ 12,800$ for firms with less than 1000 employees, $\$ 13,400$ for firms with more than 1000 and less than 5000 employees, and $\$ 25,600$ for firms with more than 5000 employees. The difference between smaller and larger firms was more pronounced in machinery and instruments and less pronounced in petroleum and electrical equipment. Schmookler attributed some of the difference to measurement problems, but he also suggested that smaller firms were more efficient innovators.

56. These results have been replicated by more recent studies. Scherer (1983b), using the FTC Line of Business data for 1974 at the business unit level (for 4274 business units), complemented by equally rich data on patents, ran regressions of patent counts on $R \& D$ expenditure and its square for 124 industries with at least five patent-receiving business units. He found increasing returns in $15.3 \%$ of the industries, decreasing returns in $25 \%$ of the industries, while in the remaining cases there was no statistically significant departure from constant returns. It should also be noted that the FTC data cover only relatively large firms. Bound et al. (1984) found that smaller US firms which do research obtain more patents relative to their $R \& D$ than larger firms, and that firms with $R \& D$ programs larger than about $\$ 2$ million have a nearly constant ratio of patenting to $R \& D$, except for the firms with the very largest $R \& D$ programs, where the ratio declines. The authors note, however, that the comparison between small and large firm patenting must be interpreted with caution, since the criteria used in the construction of the Compustat data set which they have used result in larger firms being automatically included, whether successful in R\&D or not, while it seems likely that smaller firms are included only if they have been successful in obtaining patents.

57. Hausman et al. (1984) used data on patent counts and R\&D expenditure for 128 firms for the years 1968-1974. They applied sophisticated econometric techniques involving a Poisson specification with panel data and a lag structure for the R\&D variable, and also controlled for firm and industry effects.

9. Another problem with a number of studies is the use of empirical specifications which fail to examine the relationship of R\&D productivity to firm size. For example, some authors control for firm size in regressions of innovative output on $R \& D$ outlays, or regress innovate output on $R \& D$ intensity. They therefore obtain results on the impact of $R \& D$ on innovative output when firm size is kept constant, which is not the key issue in this line of research. 
They found evidence of decreasing returns in the patents-R\&D relationship. Using simpler methods, Acs and Audretcsh (1991) obtained similar results for the innovations-R\&D relationship using a pooled sample of 732 US firms in 14 sectors. These results were quite robust with respect to controlling for technological opportunity by including in the model either fixed effects or R\&D intensities at the sector level. The results were also robust with respect to including or not in the sample firms with zero innovations (426 firms out of a total of 732). To test for possible variations across sectors, the authors also estimated the model separately for each sector. They found evidence of decreasing returns in most sectors, including chemicals, computers and office equipment, electrical equipment, motor vehicles, and instruments; increasing returns in petroleum; and constant returns in pharmaceuticals, foods and tobacco, and an aggregation of all industries with $\mathrm{R} \& \mathrm{D}$ to sales ratio lower than $1 \%$. They also found, however, that in some of the sectors exhibiting decreasing returns the single largest firm was an exception to this pattern. This may indicate that scale economies exist at very high levels of $R \& D$ expenditure in some sectors, but it may also be due to the exceptional R\&D productivity of a small number of leading industrial firms.

58. It may be asked whether innovations introduced by large firms are, on the whole, more important or have higher market value than innovations by small firms. The Gellman Research Associates' first report (1976) found that small and large innovative US firms outperformed medium-sized innovative US firms as producers of "radical" innovations (see section 2.1). Acs and Audretsch (1988) found no statistically significant difference between large and small firms with respect to the "significance" of innovations in a sub-sample of 4938 innovations from the US Small Business Administration database. They pointed out, however, that their definition of "significance" did not necessarily reflect market value. On the other hand, Scherer (1983b) reported a weak positive relationship between business unit size and the degree of complexity of systems and subsystems covered in patents. Since it has also been argued, however, that major innovations are often inefficient initially, and the market value of small and gradual improvements is greater than the value of the basic innovation, it is somewhat difficult to interpret the above comparisons anyway.

59. On the whole, and to the extent that the measurement and sample selection problems mentioned above are not so severe as to result in serious biases, the cross-industry studies suggest that innovative output per unit of R\&D expenditure does not generally increase with firm size, and it may even decrease. There seems to be considerable variation across industries, however, although none of the cross-industry analyses has attempted to examine the factors that may account for this.

60. A recent study of the pharmaceutical industry by Henderson and Cockburn (1993) illustrates the advantages of detailed industry-level studies. The authors use highly disaggregated data at the research program level on patents and research expenditure for the discovery, as distinct from the development, of new drugs for ten major pharmaceutical companies over a period of 30 years. They regress the number of patents on research expenditure, a proxy for firm size, diversification (i.e. the number of research areas) at the firm level and its square, firm dummies and a time trend. The use of data on innovative inputs and output at the research program rather than the firm level allows for interesting interpretations of the coefficients on firm size and diversification. The coefficient on firm size is positive and significant, implying that a given research program is more productive the larger the firm, while the relationship between patents and diversification, given firm and research program size, has an inverted-U shape. These results suggest, according to the authors, that there are economies of scale and scope up to a certain point in the research for discovery of new drugs.

61. Finally, Cohen and Klepper (1994) have argued that the apparently negative relationship between R\&D productivity and firm size need not imply a disadvantage of large firms in R\&D. Suppose the marginal productivity of $R \& D$ is diminishing, i.e. innovative output increases less than proportionately with $R \& D$. Then R\&D productivity falls as firm size increases simply because large firms do more $R \& D$ 
(in absolute terms) than small firms. Cohen and Klepper argue that since R\&D is a fixed cost, net returns to $R \& D$ are higher the larger the level of output over which this cost can be spread. In other words, net returns to $R \& D$ are higher for larger firms, which is the main reason why these firms spend more on R\&D than smaller firms, and are thus subject to lower R\&D productivity. It follows that this lower productivity does not reflect any disadvantage of large firms. Clearly, the idea that cost spreading is an important factor in the R\&D-size relationship is crucial to the whole argument. Cohen and Klepper indirectly test their cost spreading model using the FTC Line of Business data. They find that firm size explains an average of 15\% of the variance in business unit $\mathrm{R} \& \mathrm{D}$, while business unit size explains an average of $65 \%$ of this variance. Hence R\&D seems to be tied to business unit size rather than firm size, which is consistent with the cost spreading hypothesis. Second, they find that the relationship between R\&D and business unit size is weaker in those industries and types of innovations where cost spreading matters less: industries where the expected growth rate due to innovation is high or where innovations can be sold in disembodied form. The implication of the Cohen and Klepper study is that it may be misleading to focus on R\&D productivity alone, and that the existence of indivisibilities in R\&D should also be taken into account when drawing inferences concerning the "optimal" scale for innovation.

\subsection{Diversification}

62. The focus on diversification has been motivated by at least three different hypotheses associating diversification with the innovation-firm size relationship. The first, already suggested by our discussion of the Henderson and Cockburn study above, is that large diversified firms can benefit from positive spillovers between the various research programs they undertake; this is then an argument about the existence of economies of scope. The second hypothesis is that large diversified firms are in a better position to exploit unforeseen innovations. The idea here is that the results of research, especially basic research, are often unpredictable, and a diversified firm has more opportunities to exploit the new knowledge outside the product line for which the original research was done. The third hypothesis is that large firms can undertake many projects at any one time and hence spread the risks of R\&D. All three hypotheses imply that R\&D intensity is higher in large than in small firms because large firms can diversify into many research areas or markets.

63. It is difficult to distinguish between these various mechanisms empirically, so most studies in this area have simply examined the relationship between diversification and innovative activity. A serious problem in this literature is that the measure of diversification may partly reflect pure industry or product line effects: if a firm whose primary product line requires a high level of R\&D intensity diversifies into unrelated product lines, its R\&D intensity will most probably fall for simple statistical reasons; and conversely for a firm whose primary product line involves a low level of R\&D intensity. As, in addition, many studies have used rather crude measures of diversification, such as the number of industries in which a firm operates, it is questionable whether much can be learned from most of the literature in this area. Results have, in any case, been mixed (see Kamien and Schwartz 1982, Cohen and Levin 1989). However, one study which has focused on basic research, as distinct from applied research and development activities, of 250 US firms has found a positive relationship between diversification, measured as the number of 4-digit industries in which a firm operates, and basic research intensity, i.e. the ratio of expenditure on basic research to firm size, after controlling for firm size, technical opportunity and other variables (Link and Long 1981).

64. A number of recent studies have tried to tackle these problems. Henderson and Cockburn, in the study discussed above, have used dissagreggated data at the research program level. Another approach has been to distinguish between diversification in technologically related and in technologically unrelated industries. Scott (1993, chapters 9 and 10) divided his sample of 355 firms taken from the FTC Line of 
Business data into "purposively" and "non purposively" diversified. The former group contained those firms which had diversified into related industry categories, the latter included firms diversified into unrelated industries and undiversified firms. Scott, using simple statistical tests, found that, although purposively diversified firms may have higher or lower R\&D intensities in particular industries than firms that have not purposively diversified, there is a significant overall tendency for the R\&D intensities of the purposively diversified firms to be higher. It may be tempting to interpret this result as evidence consistent with those hypotheses emphasising the role of diversification in exploiting complementarities, although, on the other hand, it cannot be said to refute the risk spreading hypothesis. There is, however, one important caveat: diversification, especially in related industries, may itself be the result of accumulated R\&D capital stock in the primary industry; or, as Pavitt (1984) has argued, diversification in related industries may be favoured in science-based high technology sectors.

65. The hypothesis that large firm size may be conducive to innovation because of risk spreading has been tested in an entirely different framework in a study by Wedig (1990). Using a panel of 214 firms for the years 1972, 1977 and 1981, he regressed an index of systematic risk at the firm level, namely the firm beta risk, on a set of variables including R\&D intensity, R\&D intensity interacted with concentration, and firm size. He found strong evidence of a considerable systematic risk premium associated with R\&D, but only weak evidence that concentration and firm size reduced this risk premium: the coefficients on the interaction variables had the correct sign but were more often insignificant than significant.

66. In conclusion, the evidence on the hypothesis that diversification favours innovative activity is inconclusive. Because of measurement and endogeneity problems, it will be hard to obtain definitive results in this area. There are signs that there may be a positive relationship between diversification into technologically related industries and $\mathrm{R} \& \mathrm{D}$, but it is not clear whether this reflects a causal relationship and, if so, what is the direction of causality. There may also be considerable variation in the relationship across industries.

\subsection{Financial constraints}

67. Some of the most frequently invoked arguments to support the Schumpeterian hypotheses of a positive effect on innovative activity of market power, on the one hand, and firm size, on the other, start from the observation that capital markets are imperfect. R\&D activities, on the other hand, involve a larger or smaller amount of sunk costs, i.e. costs incurred before production takes place and indepedent of the gross returns from the innovation. In addition, $R \& D$ activities involve a high level of risk. It seems then likely that the availability of internal and external finance will impose a major constraint upon plans to undertake or expand R\&D activities. This is the reason why firm size or market power may matter. Two different hypotheses are typically advanced in this context. It is argued, first, that R\&D intensity is higher in concentrated industries because firms with greater market power are better able to finance R\&D from own profits; and, second, that R\&D intensity is higher in large than in small firms because large firms have better access to external finance.

68. The preponderant role of internal funds for the financing of innovation is well documented, although it is hard to say to what extent this is due to the difficulty of obtaining external funds for risky projects rather than to the firms' own reluctance to raise debt for such projects. In a study of investment, R\&D investment and sources of finance in a large panel of 1678 US firms with significant R\&D programs over the period 1976-1987, Hall (1992) found evidence of a strong negative correlation between R\&D intensity and leverage. Two measures of R\&D intensity, namely the share of R\&D investment in total investment and the share of knowledge capital stock in total capital stock, and two measures of leverage were used. In all cases the correlation coefficient was negative, suggesting that more R\&D-intensive firms 
have relatively less debt in their capital structure than less R\&D-intensive ones. In a comparative study of 130 high technology small firms in South-East England, Scotland and the San Francisco Bay area, Oakey et al. (1988) found that more than two thirds of the firms in each region relied on own profits as the main source of investment finance. Somewhat different results were obtained by Board et al. (1993). Using data on 114 R\&D performing US firms for the period 1987-1990 and 233 R\&D performing UK firms for 1990, these authors found a negative relationship between $R \& D$ intensity and gearing (i.e. the proportion of debt in a firm's capital structure) in both countries. However, they also found that when R\&D performing firms were compared to firms not engaged in $\mathrm{R} \& \mathrm{D}$, average gearing was lower for the former group in the US but not in the UK.

69. The hypothesis that firms with greater market power are more innovative because they are better able to finance $R \& D$ from own profits has provided the rationale for examining the relationship between cash flow and innovative activity. A positive relationship would be taken to imply that liquidity constraints do affect $R \& D$ and that firms which are less constrained spend more on $R \& D$, everything else being equal. From this, and the implicit assumption that cash flow is increasing in the degree of market power of the firm, a confirmation of the initial hypothesis that the existence of financial constraints favours innovation by firms with market power would follow. The main difficulty with this approach lies in the interpretation of the coefficient on the cash flow variable: actually, it need not reflect the effect of liquidity on innovation, and hence the existence of financial constraints, at all.

70. The literature on innovation and cash flow has, on the whole, provided some support for the hypothesis of a positive relationship between these two variables. Results from early studies have been ambiguous. For example, Scherer (1965b) found no evidence of any relationship between R\&D or patenting, on the one hand, and liquidity or profitability, on the other, in his sample of 448 of the largest US firms in 1955. However, in Grabowski's (1968) study of the determinants of R\&D intensity in a small sample of firms in the US chemical, pharmaceutical and petroleum industries, the coefficient on the (oneyear lagged) liquidity variable was positive and highly significant in all three industries. An attempt to distinguish between profitability and cash flow measures was made by Elliott (1971), who interpreted the former as proxies for expected profitability and the latter as indicators of liquidity. Using a panel of 53 US firms over 14 years, he found that most, but not all, of his profitability measures were stronger influences on R\&D intensity than his cash flow measures. More than anything else, this study illustrates the difficulties involved in interpreting the variables typically used in this literature as measures of liquidity rather than signals of expected future profitability of R\&D. In their survey of this literature, Kamien and Schwartz (1982) concluded that the evidence of a positive effect of either liquidity or profitability on innovation was weak, but they also pointed out that liquidity or profitability may be "threshold factors", i.e. necessary in some degree for $R \& D$ activity, but having little effect on $R \& D$ intensity above the threshold.

71. Recent studies have been, on the whole, rather more favourable to the hypothesis of a positive innovation-cash flow relationship. Hall (1992), in the study mentioned above, regressed the ratio of R\&D investment to capital stock on the ratio of cash flow to capital stock and other variables. Various specification tests were conducted and the best specification was in first differences, with controls for firm-specific effects and with two-year and three-year lags of the level variables used as instruments for the independent variables. The elasticity of $R \& D$ investment with respect to cash flow was unambiguously positive. Switzer (1984), using a cross section of 125 firms and a four-equation system to explain R\&D expenditure, capital expenditure, divident payments and new debt financing versus internal financing, found some weak evidence of a positive relationship between $R \& D$ expenditure and internal financing: the relevant coefficient was significant at the $20 \%$ level. 
72. Himmelberg and Petersen (1994) worked with a panel of 179 small firms (with a replacement value of capital stock of less than $\$ 10$ million) from the four most $\mathrm{R} \& \mathrm{D}$-intensive 2-digit sectors (chemicals and pharmaceuticals, machinery, instruments, electrical equipment and communications) over the period 1983-1987. They regressed R\&D investment on cash flow and other variables, controlling for firm-specific and time effects, and found a highly significant positive effect of internal financing on R\&D investment for a variety of specifications. The authors also mentioned that a comparison of these results with their own preliminary results for larger firms and with Hall (1992) suggested that larger firms were financially constrained as well, although to a lesser degree than smaller firms: the cash flow coefficient was lower but still significant for larger firms.

73. Not all recent studies have found a positive innovation-cash flow relationship, however, and a few authors have even reported negative coefficients on cash flow. Antonelli (1989) obtained an inverted$\mathrm{U}$ relationship in his study of $86 \mathrm{R} \& \mathrm{D}$ performing Italian firms over three years. He interpreted this as evidence that "traditional" firms which were making low profits were involved in heavy R\&D investments in an attempt to adapt to the more competitive environment of the 1980s, while for "modern" profitable firms the Schumpeterian view of cash flow constraining innovation was confirmed. This study best illustrates the main limitation of this literature, namely the interpretation of the cash flow variable. For example, although many authors would interpret a positive coefficient as evidence of financial constraints on R\&D activity, it might well reflect either expected future profitability or the profitability of past R\&D investment. Cohen (1995) has suggested that distinguishing between the cash flow of the firm as a whole and that of the business unit may help resolve these ambiguities, because firm cash flow is less likely than business unit cash flow to reflect past R\&D productivity or expected future profitability. This has not yet been done in the literature, however.

74. The second hypothesis regarding financial constraints is that R\&D intensity is higher in larger firms because these firms have better access to external finance. Unfortunately, there is only limited direct evidence on this hypothesis. While a number of studies have examined various aspects of the financing of $\mathrm{R} \& \mathrm{D}$ either in general or for small firms in particular, systematic comparisons between small and large firms have rarely been made.

75. Based on results from a large survey of "barriers to innovation" in 9 EC countries in the late 1970s, Piatier (1984) concluded that the greatest barriers were related to external finance and that smaller firms had greater difficulty in obtaining funds for R\&D than larger firms and paid higher interest rates. Rothwell and Zegveld (1982), summarising their discussion of government policies towards innovation in the late 1970s, pointed out that in most industrial countries the bulk of government subsidies for R\&D had gone to financing projects in large firms (see also Piatier 1984). According to Prakke (1988), conditions have improved during the 1980s, as a considerable growth in the supply of venture capital has taken place, first in the US, then in Europe, which has improved the chances of new small high-technology firms to obtain external financing. In Europe, governments have been heavily involved in the supply of venture capital: $21 \%$ of total venture capital funds in 1985 were public funds. This has been part of a more general shift in public R\&D policy in favour of small firms and cooperative research (Oakey et al. 1988, chapter 2; see also Metcalfe 1994 for the UK, Malerba 1993 for Italy, Bernard and Quéré 1994 for France ${ }^{9}$ ).

76. There is some evidence, however, that problems remain. Himmelberg and Petersen, in the study discussed above, have found that the impact of cash flow on R\&D appears to be smaller for larger firms, which they have interpreted as evidence that larger firms are financially constrained to a lesser degree than

10. Bernard and Quéré (1994) report that public funding of R\&D activities of small firms in France increased as a percentage of total R\&D subsidies from 3\% in 1978 to $8 \%$ in 1990. 
smaller firms. Conditions are likely to vary across countries. For example, in a comparison of US and UK sources of finance for "new technology-based firms", Mason and Harrison (1994) have argued that UK firms are likely to experience greater financial constraints because informal venture capital (i.e. funds invested by wealthy individuals in high technology firms) is much smaller in the UK than in the US.

77. More detailed information on the financial constraints faced by small firms which engage in innovative activities comes from a number of surveys. Oakey et al. (1988) have conducted two surveys to examine the financing sources of high technology small firms in South-East England, Scotland and the San Francisco Bay area. The first survey was conducted in 1981-2 and covered 174 firms, the second in 1985-6, covering 130 firms. The large majority of these firms performed internal R\&D, but some firms mainly relied on external technical information sources. A major finding was that more than two thirds of the firms in each region relied on own profits as the main source of investment finance. The authors also report that a number of firms had been refused bank funding, and a comparison between the growth rates of these firms and those which either had obtained or had not applied for bank funding showed no significant differences between the two groups. The percentage of firms that received some government aid was highest in Scotland (around 75\%), lower in South-East England (20\% in 1981-2, but 45\% in 19856) and lowest in the San Francisco Bay area (less than 10\%). Finally, the fraction of firms which claimed that they had been unable to proceed with an innovation because of lack of funds was about 10-15\% on average, with some variation across regions and time periods. These numbers are not very informative, however, in the absence of any comparison with larger firms or with small firms not engaged in innovative activities.

78. There is also evidence from the literature on small firm finance that interest rates on bank loans tend to be negatively related to firm size in many countries (see, for example, the numbers reported in Bardos 1990 for the UK, Germany, France and Italy). This is to a large extent due to the fact that small firms are correctly evaluated by the banks as more risky, on average, than large firms, since they have a higher probability of failure. However, it may also be partly due to fixed costs in assessing applications for finance, the bargaining power exerted by large buyers, or the use by bank managers of performance critiria unfavourable to smaller firms. One study which has attempted to assess the extent to which differences in loan rates reflect differences in risk is the study by Bardos (1990). Using data from French surveys, this author classified some 8000 firms into seven groups according to an index of risk constructed in a somewhat ad hoc manner on the basis of various economic and financial performance criteria. The sample was not confined to innovative firms, and contained both large and small firms. Bardos concluded that the negative relationship between firm size and the interest rate persisted even when controlling for the level of risk.

79. A number of UK studies have examined the extent to which small firms face difficulties in raising finance for start-up or growth (see Hall 1989, Mayer 1992 and DTI 1991, appendix 2 for reviews of this literature). The main findings can be summarised as follows. First, small firms are required to pay a higher interest rate and offer a higher level of security than larger firms, although it is difficult to know to what extent this is a result of market failure rather than risk differentials. Second, there are many more financial avenues open to large firms than to small ones and there is also evidence that a considerable fraction of the overall supply of venture capital has not actually been directed towards small innovative firms during the 1980s. Third, while there is no evidence of a general shortage of funds for small firms, it seems that for certain classes of small firms, namely fast growing, innovative or starting up firms, there are sometimes difficulties in raising finance, although again this does not necessarily imply that the financial market is not operating efficiently in these cases.

80. Finally, two recent UK studies have examined, first, whether innovative or high-technology small firms are more likely than other small firms to experience financial constraints, and, second, 
whether, within the class of small innovative firms, firm size is related to the probability of being constrained. According to a report based on a survey of 1095 small firms by Aston Business School (DTI 1991), only 7.6\% of "future growth-oriented" firms that were involved in investment only without any attempt to innovate at the same time had experienced problems in raising finance, but this percentage rose to around $18 \%$ for firms with projects involving either product or process innovation. On the other hand, Moore (1994), using data from a survey of 2028 UK small firms, found little evidence of a significant difference in availability of finance during early growth and subsequent maturity between high-technology and low-technology small firms; only within the class of fast growing small firms were high-technology firms more likely to be constrained than conventional firms. In the same study, Moore found evidence of a statistically significant negative firm size effect on the probability of being financially constrained when he ran regressions controlling for the type of firm (high or low-technology), firm age, rate of growth, profitability and certain other factors. Hence, within the class of small high-technology firms, smaller firms were more likely to be constrained than larger ones, other things being equal.

81. To sum up. There appears to be some evidence that the existence of financial constraints may restrict innovation by small firms and firms with little market power. This evidence is consistent with the Schumpeterian hypotheses on the role of financial constraints. A note of caution is necessary here, however, as some of the results, namely those regarding the innovation-cash flow relationship, are open to alternative interpretations, and others, in particular those on the availability of external finance for small innovative firms, are not conclusive in the absence of systematic comparisons with large innovative firms. It should also be emphasised that the existence of financial constraints does not necessarily imply that financial markets are operating inefficiently.

\subsection{Appropriability conditions}

82. According to another hypothesis, R\&D intensity is higher in concentrated industries because firms with greater market power are better able to appropriate the returns from innovation and hence have better incentives to innovate. A number of issues need to be examined in this context. First, the role of the patent system in ensuring appropriability and the extent to which this system may be favourable to firms with greater market power. Second, the role of other mechanisms ensuring appropriability, such as secrecy, lead time, investment in marketing and customer service, learning by doing, and control of distribution channels, and the extent to which firms with market power are in a better position to benefit from such mechanisms. Third, the effect of appropriability conditions on the incentives to perform R\&D.

83. There is strong evidence that industries differ considerably with respect to the role of patents in ensuring appropriability. In fact, in most industries patents are seldom regarded as an essential incentive for innovation. Taylor and Silberston (1973), using data on 27 UK firms in four sectors, found that most $R \& D$ in pharmaceuticals and some $R \& D$ in chemicals would not be undertaken in the absence of patent protection, but only a very small fraction of $R \& D$ in mechanical engineering and electronics would be affected. Mansfield et al. (1981) examined the estimated effect of patent protection on imitation costs for 43 product innovations in the same four sectors in the US. He found that the median estimated increase in imitation costs due to patent protection was $30 \%$ in ethical drugs, $10 \%$ in chemicals and $7 \%$ in machinery and electronics. Mansfield (1986) asked a random sample of 100 US large firms from 12 sectors to estimate the proportion of inventions developed in 1981-83 that would have not been developed, or commercially introduced, without patent protection. In only three sectors, namely pharmaceuticals, chemicals and petroleum, was this proportion higher than $20 \%$ (for pharmaceuticals it was $60 \%$ ), while in 2 sectors, namely machinery and fabricated metal products, it was between $10 \%$ and $20 \%$, and in 7 sectors 
it was lower than $10 \% .{ }^{10} \mathrm{~A}$ more comprehensive study of appropriability conditions was undertaken by Levin et al. (1987), who conducted a survey of R\&D executives in 130 industries. Patents were thought to be highly effective as a means of preventing duplication in only five industries (including drugs), and quite effective in another 20 industries. For process innovations, only three industries regarded patents as highly or quite effective (i.e. rated higher than five on a seven-point scale of effectiveness). The overall sample means on a seven-point scale of effectiveness were 3.52 for process patents and 4.33 for product patents.

84. Despite the fact that patents do not seem to be regarded as a necessary incentive for innovation in most industries, it may be asked whether the patent system tends to be more favourable to firms with greater market power. Very little direct evidence on this question is available. Certainly smaller firms seem to obtain a larger number of patents per unit of R\&D expenditure than larger firms (see section 3.2 above). Also, Scherer (1983b) found, using the FTC Line of Business data and matched data on patents, that industry concentration had no impact on the number of patents per unit of $R \& D$ expenditure at the business unit level. On the other hand, Mansfield (1986), in the study discussed above, found a positive and statistically significant correlation between firm size and the percentage of patentable innovations which were patented in the three sectors (pharmaceuticals, chemicals, petroleum) where patents seemed to be most important. These results are not very informative as to whether the patent system does or does not favour firms with higher market power, however, since many effects are involved in these relationships.

85. An important issue in this context is whether firm size or market power is related to the ability of patent holders to enforce their rights against alleged infringers. This may depend on specific characteristics of the patent system in each country. For the US, Scherer (1991) analysed 148 patent case decisions between 1983 and 1988 and found no evidence that smaller firms, i.e. firms with sales of less than \$25 million, were at a disadvantage relative to larger firms. Large patent holders won in 15 out of 25 cases against small firms and in 19 out of 35 cases against other large firms. Small patent holders won in 15 out of 28 cases against large firms and in 26 out of 41 cases against other small firms (some cases were not classifiable).

86. The main reason for the limited effectiveness of patents seems to be that competitors can legally "invent around" patents (Levin et al. 1987). Other reasons include possibly stringent legal requirements for proof that a patent is valid or that it is being infringed, and the disclosure of information through patent documents. In many industries, however, firms find other means of appropriation to be quite effective. Investment in complementary sales and service efforts was regarded as highly effective in $80 \%$ of the 130 industries in the Levin et al. sample. Other mechanisms mentioned in this study included secrecy, imitation costs and lags, and the ability to move down the learning curve. The effectiveness of each of these mechanisms was shown to vary across industries. However, the relationship between appropriability conditions and other industry-specific characteristics such as market structure was not examined.

87. Levin et al. have also argued that a shortcoming of their study is that it has focused on relatively large firms and may have thus understated the role of patents in ensuring appropriation of returns to R\&D. The idea here is that it may be infeasible for a small firm to invest in complementary sales or customer service or to move down a learning curve. This criticism also applies to Mansfield (1986) and Mansfield et al. (1981). Both these studies have examined whether patent protection is more important for smaller firms

11. The fact that patent protection was not seen as essential in the majority of sectors did not mean, however, that patents were not used. In the 7 sectors where patents seemed less important, the average ratio of patented to patentable innovations was 0.6 , compared to 0.8 for the 5 remaining sectors. Note, however, that there may be motives for using patents that are not related to the appropriation of returns to $R \& D$ (see Levin et al. 1987). 
than for larger ones. Mansfeld et al. (1981) estimated a logit model to see whether the probability that an innovation would have been introduced without patent protection was affected by firm size, and found no significant effect, but their sample was quite small. Mansfield (1986) correlated firm size with the proportion of a firm's inventions that would have not been developed in the absence of patents in each of 10 sectors. The correlation coefficient was negative and statistically significant in one sector, positive and significant in two sectors, and insignificant in the remaining seven sectors. However, the sample did not include any firms with sales below $\$ 25$ million; the result might have been different if small firms had been included. On the other hand, there is hardly any systematic evidence on whether there is a relationship between firm size or market power and the effective use of appropriation mechanisms such as secrecy, lead time, and investment in marketing and customer service.

88. Finally, it should be noted that while the literature on the Schumpeterian hypotheses has typically taken for granted that appropriability has a positive effect on R\&D incentives, the scant empirical evidence on this issue is mixed (see Cohen 1995). Moreover, little is known on the extent to which the effect depends on industry-specific characteristics.

89. In conclusion, we still know very little on the factors that account for the observed inter-industry variation in appropriability conditions. It remains an open question whether firms with greater market power are in a better position to benefit from patents or other mechanisms of appropriating returns from innovation. Finally, the more fundamental question of whether appropriability has actually a positive effect on R\&D incentives also remains unresolved.

\section{Other themes}

90. This section will discuss recent empirical work which has thrown some light on a number of mechanisms relating innovation to market structure with an emphasis on the endogeneity of both these variables. Most of these studies are based on theoretical models of market structure and the innovative process and all of them go beyond the Schumpeterian hypotheses by emphasising primary factors like technology, the characteristics of demand, the institutional framework, strategic interaction and chance. Three themes will be explored:

1. First mover advantages, such as learning by doing, and disadvantages, such as organisational inertia, and their implications for the evolution of market shares and technological leadership.

2. Demand characteristics, such as the degree of product differentiation, and their implications for the trade-off between product enhancement and product proliferation and for market structure.

3. Stochastic patterns of firm innovation and growth and their implications for the evolution of market structure over the industry life cycle.

91. An advantage of these recent studies over the cross-industry econometric literature on the impact of innovative activity on market structure lies in the fact that they focus on specific mechanisms relating the two variables. In fact, the existence of a variety of such mechanisms may be part of the reason why the cross-industry econometric literature has been inconclusive. For example, while Levin and Reiss (1984, 1988) and Farber (1981) found a positive effect of R\&D intensity on concentration in the context of simultaneous equation systems, Mukhopadhyay (1985) found a negative effect of R\&D intensity on concentration change and Geroski and Pomroy (1990) found a negative effect of innovation counts on concentration change. Moreover, the econometric results may be difficult to interpret, because innovation may affect market structure directly or indirectly and in various ways: because of fixed costs of $\mathrm{R} \& \mathrm{D}$, or 
by affecting the pattern of firm growth in an industry, or by increasing or decreasing the minimum efficient scale of production, or because innovative activity can either facilitate or hinder entry of small firms. On the whole, little has been learned from most of these studies about the specific ways in which innovation and market structure interact. More has perhaps been learned from case studies, such as the Phillips (1971) monograph on the evolution of the US commercial aircraft industry discussed in section 2.2 above, or the Mansfield (1962) analysis of the (positive) impact of innovation on firm growth in the US steel and petroleum refining industries since the First World War.

92. A general underlying theme in much of the recent literature on market conduct and structure is the notion that equilibrium outcomes in oligopolistic industries depend on a number of factors, some of which are either not observable or not systematic. For instance, a well known feature of theoretical models of oligopoly is that equilibrium outcomes very often depend on the order of moves or on assumptions regarding the agents' beliefs about their rivals. The empirical study of business strategy, on the other hand, provides numerous examples of how the evolution of an industry can be affected by accident and personality. This dependence on unobservable or non systematic influences has important implications for the analysis of markets, because it means that, for any given set of values of the measurable and systematic exogenous factors, there is a multiplicity of possible outcomes. While for some problems the best approach may still be to regard these influences as random noise, for others a different approach may be more useful. Sutton $(1991,1995)$ has advocated the use of a "bounds" approach for the study of market structure. This involves placing bounds on the space of outcomes and thus excluding certain outcomes as either impossible or unlikely. For example, in Sutton (1991) a lower bound to concentration is proposed, which corresponds to a situation where each of a number of symmetric single-product single-plant firms operates at a level of output equal to the minimum efficient scale level. While the equilibrium level of concentration cannot be lower than this bound, it can be higher to the extent that an industry comprises asymmetric multi-plant or multi-product firms or firms operating above the minimum efficient scale level. In Sutton (1995) a tighter lower bound to concentration is identified, which corresponds to a distribution of firm sizes within an industry generated by a specific stochastic process of firm growth in addition to certain exogenous deterministic factors.

93. The endogeneity of both innovative activity and market structure, on the one hand, and the multiplicity of possible equilibrium outcomes, on the other, are the key elements of the new learning on the links between innovation and market structure. Against this general background, a number of specific mechanisms have been examined in recent studies. A number of studies have focused on factors determining the evolution of technological leadership and market shares in R\&D-intensive industries. Using a formal model of vertical product differentiation and evidence from the market for semiconductor memory chips, Gruber (1992a, 1992b, 1995) has focused on firm-specific learning by doing as a mechanism which generates stability of market share patterns over a sequence of product innovations. In particular, he has examined the relevance of learning by doing in the production of two different types of semiconductor memory chips, namely dynamic random access memories (DRAMs) and erasable programmable read only memories (EPROMs). Firm-specific learning by doing is very important in the production of EPROMs, not only because cumulative output reduces the production cost of a given quality, but also because it lowers the cost of adopting the successive quality: the firm who enters early into a new generation of EPROMs gets a better idea of how to improve the quality compared to a late entrant. Gruber draws a link between the importance of learning by doing, on the one hand, and the regularity of market share patterns over successive generations of EPROMs, on the other. One firm, the technological leader, has consistently been the first firm to introduce new generations and has had an initially high and then decreasing world market share in each generational cycle. A second firm has consistently adopted a follower strategy and has tended to have a more or less constant market share in each generational cycle. Finally, a third firm has been a late entrant and its market share has been initially 
low and then increasing in each generational cycle. Learning by doing is less relevant in the case of DRAMs, however, and this may be part of the reason why "leapfrogging" has occured in this market.

94. Learning by doing may generate a first mover advantage in products where quality improvement is a relatively continuous and largely predictable process. Other factors, however, may favour the leapfrogging of a technological leader, especially when improvements are less predictable and technological discontinuities, i.e. changes from one group of products or processes to another, occur. Foster (1986) has looked at a large number of cases of leapfrogging across a wide range of industries and has identified a number of potential incumbent firm disadvantages in innovation. Due to the uncertainty involved in all innovative activity, a technological leader may have difficulty realising that he has reached the region of diminishing returns to the effort put into improving an existing product or process. In addition, a technological leader may be tempted to stick to an existing technology too long because of organisational inertia or in order to maximise the returns on his sunk investment. As a result, the leader is likely to be leapfrogged when a significant change in technology takes place.

95. Similar ideas have been advanced in a recent study by Swann and Gill (1993a, 1993b). Their main hypothesis is that technological change which is consistent with a widely accepted vision of the future of a technology will tend to favour incumbent firms, because of the existence of static scale economies and dynamic learning economies, and hence be concentrating, at least in the short to medium term. On the other hand, technological change which conflicts with widely held expectations about the future of a technology and hence is disruptive to existing organisational structures (for example, a radical redefinition of the product or the introduction of a new process) will have a deconcentrating effect, as entrants will take opportunities that incumbent firms will fail to exploit because of organisational inertia. Swann and Gill constructed a simulation model to illustrate these ideas. They also examined evidence from case studies of five high technology markets, namely microprocessors, memory chips, standard logic chips, PC software and biotechnology, which seemed, on the whole, to be consistent with their hypothesis. In the PC software case, for instance, rapid incremental change of a predictable sort, namely the sequence of upgrades to a particular software package, has tended to be concentrating, while radical innovations which have created new software categories have tended to be deconcentrating.

96. These recent studies have taken a first step towards a better understanding of the factors determining the evolution of technological leadership and the degree of turbulence in R\&D-intensive industries. The main focus has so far been on the characteristics of technology itself, such as the degree of continuity of technology and the extent of learning economies in innovation, and on the organisational structure of the firm. Future work may analyse the role of additional factors, such as appropriability conditions, and also examine more closely the link between turbulence and concentration in R\&Dintensive industries, since one can think of situations where high turbulence is not deconcentrating in the medium to long term or persistence of technological leadership is not concentrating.

97. The second theme explored in the recent literature relates to the implications of demand characteristics, such as the degree of product differentiation, for the trade-off between product enhancement and product proliferation and for market structure. The starting point of the theoretical and empirical analysis in Sutton (1996) is the search for industry-specific exogenous parameters that are important determinants of both R\&D intensity and concentration. Two such key parameters are identified. The first is the elasticity of the $R \& D$ cost function, a technological characteristic. Broadly interpreted, this is a measure of the returns from improving the technical performance or quality of an existing product. The second is the degree of horizontal product differentiation, a demand characteristic. This is a measure of the degree to which demand is fragmented due to the existence of a variety of customer tastes or requirements; it therefore indirectly reflects the returns from introducing a new product. Sutton argues that an important trade-off in high technological opportunity industries is between spending in R\&D to 
enhance the quality of an existing product and spending to develop a new product. The former strategy will result in a relatively high level of concentration, as incumbent firms get caught in a process of R\&D escalation leading to a rise in $R \& D$ expenditures. This will cause a rise in concentration, since firms cannot cover these expenditures unless their number falls and each firm produces more output. The latter strategy will result in a relatively low level of concentration, as the possibility of developing new varieties that match the needs of particular buyers leads to a proliferation of varieties and attracts new entry. Both strategies are associated with a high level of R\&D intensity, which is itself endogenously determined. This whole argument is cast by Sutton within the "bounds" approach to market structure discussed above.

98. The empirical analysis of these ideas in Sutton (1996) involved both the formulation of theoretical predictions that could be tested across industries and the analysis of case studies. The main prediction related to the relationship between the degree of product differentiation and market structure in R\&D-intensive industries: the lower bound to concentration is expected to decrease as product differentiability rises and product proliferation increasingly dominates product enhancement. On the other hand, there is no reason to expect any relationship between product differentiation and market structure in low R\&D industries. Sutton tested this hypothesis using the FTC Line of Business data on R\&D intensity at the industry level and matched data on horizontal product differentiation (proxied as the number of 7digit product lines within each industry). He found that the lower bound to concentration decreased with product differentiability in the group of industries with $R \& D$ to sales ratio higher than $4 \%$, while there was no relationship between the two variables in the control group of industries with $R \& D$ to sales ratio lower than $4 \%$. Additional evidence on the implications of the degree of product differentiation for market structure in R\&D-intensive industries was provided through a comparison of two case studies: the photographic film industry, a case of R\&D escalation during the shift from black-and-white to colour film in the 1960s, leading to the shakeout of medium-sized firms, and the flowmeter industry, where the diversity of user requirements and the ensuing high degree of product differentiation help explain the persistence of a fragmented market structure. ${ }^{11}$ There may also be a number of additional implications of these ideas. For instance, it seems likely that demand characteristics play a less important role in industries with process $R \& D$ than in industries with product $R \& D$. One might then expect a stronger correlation between $R \& D$ intensity and concentration in the former group of industries than in the latter. It is interesting, in this respect, that Lunn (1986) has found a statistically significant positive two-way relationship between process innovation and market structure and no effect either way between product innovation and market structure, in his study of 191 US industries (see section 2.2 above). Finally, one qualification should be noted. Even though R\&D outlays are endogenously determined as a result of firms' strategic choices, there is an exogenous component as well, mainly because of indivisibilities in R\&D projects (see the section on R\&D costs above). Sutton recognised that the unit development cost of a new flowmeter is much smaller than the unit development cost of a new colour film. The average level of costs per $R \& D$ project in each industry is likely to be an important factor in explaining interindustry differences in market structure, in addition to technological opportunity and demand characteristics. While the studies discussed so far in this section have thrown some light on various aspects of innovation and the evolution of market structure in R\&D-intensive industries, they have probably not told the whole story. For instance, Sutton's (1996) study has examined the determinants of the concentration ratio at a given point in time.

12. Sutton also argues that the relevance of the degree of product differentiation for the determination of market structure does not, on the whole, merely reflect the difficulty to measure concentration at the right level of aggregation. The main reason is that $\mathrm{R} \& \mathrm{D}$ should also be measured at an appropriate level of aggregation. Hence if a market is divided into submarkets defined narrowly enough to ensure that products within each submarket are close substitutes, it may be impossible to allocate R\&D by submarkets in any meaningful way, as most R\&D may be devoted to a search for new categories. 
Another important aspect of market structure, however, is the size distribution of firms. Similarly, the literature on first mover advantages and disadvantages has analysed some of the factors determining the degree of turbulence in R\&D-intensive industries. It may also be asked whether there are any systematic patterns in the evolution of the industry life cycle in these industries. A number of recent studies have focused on some of these issues adopting a different theoretical framework than the one typically used in the industrial organisation and business strategy literatures. In particular, these studies have put little emphasis on strategic interaction and have instead analysed the implications of technological change and stochastic patterns of firm innovation and growth for the evolution of market structure over the industry life cycle. The starting point in these studies is a number of empirical regularities regarding the industry life cycle that seem to hold across a considerable number of high technological opportunity industries (see for example Gort and Klepper 1982, Klepper and Graddy 1990, Utterbach and Suarez 1993). A first set of regularities relates to the evolution of market structure in technologically progressive industries. When such an industry is new, there is a lot of entry and turbulence, but subsequently entry slows and exit starts to prevail despite continued market growth, thus leading to a "shakeout" in the number of firms; eventually, market structure stabilises. A second set of regularities pertains to technological change in industries with rich opportunities for both product and process R\&D. Initially, many varieties of the industry's main product are offered and the rate of product innovation is high, but subsequently increasing effort is devoted to process relative to product innovation and the diversity of competing versions of the product declines. There are a number of studies that try to explain these and related patterns. According to one story, during the early stages of industry development there is experimentation with various product designs, as uncertainty is high and demand is fragmented across a number of variants. Firms are relatively small and entry is easy, as there are no significant advantages to incumbency. At some point in time, however, a dominant design or a narrow class of designs emerges and finally becomes established. Only firms that can adopt the dominant design stay in the industry. In addition, competition shifts from design to price, process innovation increasingly dominates product innovation, and economies of scale and learning become important. This induces further exit and also puts potential entrants at a disadvantage. After the shakeout, structure stabilises. It has been argued that this story describes the evolution of the US automobile industry and other industries where consumer preferences are relatively homogeneous. A

somewhat different story has been proposed by Jovanovic and MacDonald (1994). These authors started from the observation that in many industries that have experienced shakeouts there was a period of intense innovative activity immediately before the sharp fall in the number of firms. In their model, what causes the shakeout is a single major refinement to the technology of the industry which opens up new possibilities for innovation. The shakeout occurs because many firms are not successful in exploiting these possibilities and also because minimum efficient scale of production may increase as a result of the technological change. Jovanovic and MacDonald thought that this story was consistent with the evolution of the US tyre industry. Klepper (1993) has proposed still another model to explain the observed regularities in industry evolution. In contrast with the dominant design theory and Jovanovic and MacDonald (1994), there are no exogenous changes in technology, i.e. firms face opportunities for product and process innovation which do not change over time. There are three key features in the model. First, firms differ in their innovative capabilities, which are acquired randomly, do not change over time and influence the kinds of product innovations they develop. Second, firms enter at different times, depending on when they acquire their innovative expertise. Third, the returns to process $R \& D$, and hence the incentives to engage in process $R \& D$, are positively related to firm size. The basic mechanism shaping industry evolution is as follows. After an initial stage with a lot of entry, exit and product innovation, all principally driven by random firm differences, consistently successful firms gradually get bigger. As returns to process $R \& D$ are related to size, larger incumbents increase their process $R \& D$ and hence gradually magnify their cost advantage over potential entrants. So eventually entry stops, the number of firms falls, and the rate of product R\&D declines. Klepper and Simons (1993) tested this model against the dominant design theory and the model of Jovanovic and MacDonald, and thought that it explained the evolution of four US industries (automobiles, tyres, televisions and penicillin) better than these alternative 
models. Although industry life cycle theories seem to explain certain patterns which have been observed across a considerable range of industries, they have also been criticised on various grounds. It has been argued that the dominant design story, in particular, is not valid in the case of industries where demand is fragmented due to the existence of diverse consumer needs. More generally, these models may oversimplify the evolutionary process by implicitly suggesting that there are no discontinuities in the technology of the industry during the later stages of industry development, and hence incumbents can safely maintain their dominant position. Also, these models, especially the one by Klepper, may not be relevant for industries where the scope for process innovation or economies of scale is limited. Finally, their applicability in countries other than the US remains an open question. While the generality of the particular mechanisms and evolutionary paths proposed by these studies is questionable, the focus on a number of factors that have not been much analysed in the literature, namely technological events, predictable or unpredictable, and random differences between firms in innovation and growth, is certainly welcome. It is now clear that a full understanding of the interaction between innovation amd market structure involves examining the ways in which chance and technological change affect the evolution of market structure and innovative activity.

\section{Concluding remarks and policy implications}

99. This paper has reviewed the large empirical literature on the links between innovative activity, firm size and market structure. Most of this literature has been motivated by the idea that monopoly power and large firm size may have a positive effect on innovation and thus be welfare enhancing in the long run. Many studies have examined directly the impact of firm size or market structure on innovation, while others have tested a number of specific hypotheses as to why a positive effect may exist. What all these studies have in common is an emphasis on a one-way direction of causality, from market structure and firm size to innovation. This clearly constitutes a limitation, since it is now widely recognised that all these variables are endogenous. The emphasis has therefore shifted in recent work, as a number of studies have focused on mechanisms relating innovative activity and market structure within a system where the primary factors are technology, demand, the institutional framework, strategic interaction and chance. A key policy question in this area relates to the potential existence of a trade-off between static and dynamic efficiency. The present literature survey suggests that there seems to be little empirical support for the view that large firm size or high concentration are factors generally conducive to a higher level of innovative activity. Of course, once it is recognised that all these variables are endogenously determined, the emphasis shifts from causality to mere correlation. Again there is no evidence of a general positive association between innovation and market structure or firm size, although there are circumstances where a positive association exists. This implies that there is probably no general trade-off between competition policy and technical progress, although in some R\&D-intensive industries a high level of concentration may be inevitable. The policy implications of the endogeneity of market structure and firm size should be emphasised. One implication is that high concentration is not synonymous with high market power, something which competition authorities have now recognised. Another implication is that there is a limit to what can be achieved through competition and industrial policies. For instance, one cannot impose a level of concentration which, given all exogenous factors (including firms' strategic behaviour), results in margins so low that firms cannot cover their fixed costs (including $R \& D$ costs). The range of sustainable levels of concentration in any given industry will depend on a number of industry-specific factors. These include technological characteristics such as technological opportunity, the average cost of an R\&D project, the degree of continuity and predictability of technology, and the extent of learning economies; demand characteristics such as the degree of horizontal product differentiation; and aspects of strategic interaction such as the intensity of price competition. Which level of concentration will be realised within the feasible range will depend on factors which are random or difficult to measure. 
100. Concentration and firm size can also depend on merger, antitrust and industrial policies. These may affect either the range of sustainable outcomes in a given industry or, more often, the realised outcome within that range. For instance, industrial policy aimed at promoting cooperative research may in some cases allow smaller firms to share the cost of an R\&D project. However, little is known on the effectiveness of such policies; in addition, the overall welfare effect of joint R\&D need not be positive, as cooperation in research may influence the total level of R\&D or the intensity of price competition. Policy with respect to the financing of $R \& D$ can also affect market structure, by increasing the availability of external finance to financially constrained small innovative firms. However, such policies must be carefully designed to avoid creating distortions, since the existence of financial constraints need not imply that financial markets operate inefficiently. These are important issues, given the recent shift in public R\&D policy in favour of small firms and cooperative R\&D. Finally, merger and antitrust policies should also be used with care and with a view to the specific circumstances of each industry. This follows, first, from the existence of differences in the relationships between market structure or firm size, on the one hand, and innovative activity, on the other, across industries; and, second, from the fact that there is only a certain range of sustainable market structures in any given industry. 


\section{BIBLIOGRAPHY}

Acs, Z.J. and D.B. Audretsch (1987), "Innovation, Market Structure and Firm Size", Review of Economics and Statistics, 69, pp. 567-575.

Acs, Z.J. and D.B. Audretsch (1988) "Innovation in Large and Small Firms: An Empirical Analysis", American Economic Review, 78, pp. 678-690.

Acs, Z.J. and D.B. Audretsch (1990), Innovation and Small Firms, Cambridge, Mass.: MIT Press.

Acs, Z.J. and D.B. Audretsch (1991) "R\&D, Firm Size and Innovative Activity", in Z.J. Acs and D.B. Audretsch (eds), Innovation and Technological Change. An International Comparison, Ann Arbor: University of Michican Press.

Antonelli, C. (1989), "A Failure-Inducement Model of Research and Development Expenditure", Journal of Economic Behaviour and Organization, 12, pp. 159-180.

Baldwin, W.L. and J.T. Scott (1987), Market Structure and Technological Change, Chur: Harwood Academic Publishers.

Bardos, M. (1990), "Le crédit plus cher pour les petites entreprises: le risque n'explique pas tout", Economie et statistique, No. 236, pp. 51-64.

Bernard, J. and M. Quéré (1994), "L'évolution du financement public sur l'activité de recherche des PME/PMI", Revue d'économie industrielle, No. 67, pp. 211-224.

Bertschek, I (1995), "Product and Process Innovation as a Response to Increasing Imports and Foreign Direct Investment", Journal of Industrial Economics, 43, pp. 341-357.

Board, J., P.J.R. Delargy and I. Tonks (1993), "R\&D Intensity and Firm Finance: A US-UK Comparison", in P. Swann (ed.), New Technologies and the Firm. Innovation and Competition, London: Routledge.

Bound, J., C. Cummins, Z. Griliches, B.H. Hall and A. Jaffe (1984), "Who Does R\&D and Who Patents?", in Z. Griliches (ed.), $R \& D$, Patents, and Productivity, Chicago: University of Chicago Press.

Cohen, W. (1995), "Empirical Studies of Innovative Activity", in P. Stoneman (ed.), Handbook of the Economics of Innovation and Technological Change, Oxford: Blackwell.

Cohen, W.M. and S. Klepper (1994), "A Reprise of Size and R\&D, Carnegie Mellon University, mimeo.

Cohen, W.M. and R.C. Levin (1989), "Empirical Studies of Innovation and Market Structure", in R. Schmalensee and R.D. Willig (eds), Handbook of Industrial Organization, Vol. II, Amsterdam: North-Holland.

Cohen, W.M., R.C. Levin and D.C. Mowery (1987), "Firm Size and R\&D Intensity: A Re-examination", Journal of Industrial Economics, 35, pp. 543-563.

Colombo, M.G. (1995), "Firm Size and Cooperation: The Determinants of Cooperative Agreements in Information Technology Industries", International Journal of Economics and Business, 2, pp. 3-29.

Comanor, W.S. (1967), "Market Structure, Product Differentiation, and Industrial Research", Quarterly Journal of Economics, 81, pp. 631-657.

Dasgupta, P. and J. Stiglitz (1980), "Industrial Structure and the Nature of Innovative Activity", Economic Journal, 90, pp. 266-293.

Department of Trade and Industry (DTI) (1991), Constraints on the Growth of Small Firms, London: HMSO.

Dogson, M. (1993), Technological Collaboration in Industry, London: Routledge. 
Elliott, J.W. (1971), "Funds Flow vs. Expectational Theories of Research and Development Expenditures in the Firm", Southern Economic Journal, 37, pp. 409-422.

Farber, S. (1981), "Buyer Market Structure and R\&D Effort: A Simultaneous Equations Model", Review of Economics and Statistics, 63, pp. 336-345.

Foster, R.N. (1986), Innovation. The Attacker's Advantage, London: MacMillan.

Freeman, C. (1982), The Economics of Industrial Innovation, 2nd edition, London: Frances Pinter.

Gellman Research Associates (1976), Indicators of International Trends in Technological Innovation, Final Report to the National Science Foundation, Jenkintown, Penn.: Gellman Research Associates.

Geroski, P.A. (1990), "Innovation, Technological Opportunity, and Market Structure", Oxford Economic Papers, 42, pp. 586-602.

Geroski, P.A. and R. Pomroy (1990), "Innovation and the Evolution of Market Structure", Journal of Industrial Economics, 38, pp. 299-314.

Gort, M. and S. Klepper (1982), "Time Paths in the Diffusion of Product Innovations", Economic Journal, 92, pp. 630-653.

Grabowski, H.G. (1968), "The Determinants of Industrial Research and Development: A Study of the Chemical, Drug and Petroleum Industries", Journal of Political Economy, 76, pp. 292-306.

Gruber, H. (1992a), "Persistence of Leadership in Product Innovation", Journal of Industrial Economics, 40, pp. 359-375.

Gruber, H. (1992b), "The Learning Curve in the Production of Semiconductor Memory Chips", Applied Economics, 24, pp. 885-894.

Gruber, H. (1995), "Market Structure, Learning and Product Innovation: the EPROM Market", International Journal of the Economics of Business, 2, pp. 87-101.

Hagendoorn, J. and J. Schakenraad (1993), "Strategic Technology Partnering and International Corporate Strategies", in K. S. Hughes (ed.), European Competitiveness, Cambridge: Cambridge University Press.

Hall, B.H. (1992), "Investment and Research and Development at the Firm Level: Does the Source of Financing Matter?", NBER Working Paper No. 4096.

Hall, G. (1989), "Lack of Finance as a Constraint on the Expansion of Innovatory Small Firms", in J. Barber, J.S. Metcalfe and M. Porteous (eds.), Barriers to Growth in Small Firms, London: Routledge.

Hausman, J., B.H. Hall and Z. Griliches (1984), "Econometric Models for Count Data with an Application to the Patents-R\&D Relationship", Econometrica, 52, pp. 909-938.

Henderson, R. and I. Cockburn (1993), "Scale, Scope and Spillovers: The Determinants of Research Productivity in the Pharmaceutical Industry", NBER Working Paper No. 4466.

Himmelberg, C.P. and B.C. Petersen (1994), "R\&D and Internal Finance: A Panel Study of Small Firms in High-Tech Industries", Review of Economics and Statistics, 76, pp. 38-51.

Jovanovic, B. and G.M. MacDonald (1994), "The Life Cycle of a Competitive Industry", Journal of Political Economy, 102, pp. 322-347.

Kamien, M.I. and N.L. Schwartz (1982), Market Structure and Innovation, Cambridge: Cambridge University Press.

Kleinknecht, A. (1987), "Measuring R\&D in Small Firms: How Much Are We Missing?", Journal of Industrial Economics 36, pp. 253-256.

Kleinknecht, A. and B. Verspagen (1989), "R\&D and Market Structure: The Impact of Measurement and Aggregation Problems", Small Business Economics, 1, pp. 297-301.

Klepper, S. (1993), "Entry, Exit, Growth, and Innovation Over the Product Life Cycle", Carnegie Mellon University, mimeo.

Klepper, S. and E. Graddy (1990), "The Evolution of New Industries and the Determinants of Market Structure", Rand Journal of Economics, 21, pp. 27-44. 
Klepper, S. and K.L. Simons (1993), "Technological Change and Industry Shakeouts", Carnegie Mellon University, mimeo.

Kraft, K. (1989), "Market Structure, Firm Characteristics and Innovative Activity", Journal of Industrial Economics, 37, pp. 329-336.

Levin, R.C., W.M. Cohen and D.C. Mowery (1985), "R\&D Appropriability, Opportunity, and Market Structure: New Evidence on Some Schumpeterian Hypotheses", American Economic Review, AEA Papers and Proceedings, 75, pp. 20-24.

Levin, R.C., A.K. Klevorick, R.R. Nelson and S.W. Winter (1987), "Appropriating the Returns from Industrial Research and Development", Brookings Papers on Economic Activity, pp. 783-831.

Levin, R.C. and P.C. Reiss (1984), "Tests of a Schumpeterian Model of R\&D and Market Structure", in Z. Griliches (ed.), R\&D, Patents, and Productivity, Chicago: University of Chicago Press.

Levin, R.C. and P.C. Reiss (1988), "Cost-Reducing and Demand-Creating R\&D with Spillovers", Rand Journal of Economics, 19, pp. 538-556.

Link, A.N. and L.L. Bauer (1989), Cooperative Research in U.S. Manufacturing, Lexington, Mass.: Lexington Books.

Link, A.N. and J.E. Long (1981), "The Simple Economics of Basic Scientific Research: A Test Of Nelson's Diversification Hypothesis", Journal of Industrial Economics, 30, pp. 105- 109.

Lunn, J. (1986), "An Empirical Analysis of Process and Product Patenting: A Simultaneous Equation Framework", Journal of Industrial Economics, 34, pp. 319-330.

Lunn, J. and S. Martin (1986), "Market Structure, Firm Structure, and Research and Development", Quarterly Review of Economics and Business, 26, pp. 31-44.

Malerba, F. (1993), "The National System of Innovation: Italy", in R.R. Nelson (ed.), National Innovation Systems. A Comparative Analysis, New York: Oxford University Press.

Mansfield, E. (1962), "Entry, Gibrat's Law, Innovation and Growth of Firms", American Economic Review, 52, pp. 1023-1051.

Mansfield, E. (1986), "Patents and Innovation: An Empirical Study", Management Science, 32, pp. 173181.

Mansfield, E., J. Rapoport, J. Schnee, S. Wagner and M. Hamburger (1971), Research and Innovation in the Modern Corporation, London: MacMillan.

Mansfield, E., M. Schwartz and S. Wagner (1981), "Imitation Costs and Patents: An Empirical Study", Economic Journal, 91, pp. 907-918.

Mason, C. and R. Harrison (1994), "The Role of Informal and Formal Sources of Venture Capital in the Financing of Technology-Based SMEs in the United Kingdom", in R. Oakey, ed., New TechnologyBased Firms in the 1990s, London: Paul Chapman.

Mayer, C. (1992), "The Financing of Innovation", in A. Bowen and M. Ricketts (eds.), Stimulating Innovation in Industry, London: Cogan Page.

Metcalfe, J.S. (1994), "Technology Policies and Small Firms: An Evolutionary Perspective", in R. Oakey (ed.), New Technology-Based Firms in the 1990s, London: Paul Chapman.

Moore, B. (1994), "Financial Constraints to the Growth and Development of Small High-Technology Firms", in A. Hughes and D.J. Storey (eds.), Finance and the Small Firm, London: Routledge.

Mowery, D.C. and N. Rosenberg (1989), Technology and the Pursuit of Economic Growth, Cambridge: Cambridge University Press.

Mukhopadhyay, A.K. (1985), "Technological Progress and Change in Market Concentration in the U.S., 1963-1977", Southern Economic Journal, 52, pp. 141-149.

Oakey, R., R. Rothwell and S. Cooper (1988), The Management of Innovation in High-Technology Small Firms, London: Pinter Publishers.

Pakes, A. and M. Schankerman (1984), "The Rate of Obsolescence of Patents, Research Gestation Lags, and the Private Returns to Research Resources", in Z. Griliches (ed.), R\&D, Patents, and Productivity, Chicago: University of Chicago Press. 
Patel. P. and K. Pavitt (1992), "The Innovative Performance of the World's Largest Firms: Some New Evidence", Economics of Innovation and New Technology, 2, pp. 91-102.

Pavitt, K. (1984), "Sectoral Patterns of Technical Change: Towards a Taxonomy and a Theory", Research Policy, 13, pp. 343-373.

Pavitt, K., M. Robson and J. Townsend (1987), "The Size Distribution of Innovating Firms in the UK: 1945-1983", Journal of Industrial Economics, 35, pp. 297-316.

Phillips, A. (1971), Technology and Market Structure. A Study of the Aircraft Industry, Lexington, Mass.: Lexington Books.

Piatier, A. (1984), Barriers to Innovation, London: Frances Pinter.

Prakke, F. (1988), "The Financing of Technical Innovation", in A. Heertje (ed.), Innovation, Technology, and Finance, Oxford: Basil Blackwell.

Rothwell, R. (1989), "SMFs, Inter-firm Relationships and Technological Change", Entrepreneurship and Regional Development, 1, pp. 275-291.

Rothwell, R. and W. Zegveld, 1982, Innovation and the Small and Medium Sized Firm, London: Frances Pinter.

Scherer, F.M. (1965a), "Size of Firm, Oligopoly and Research: A Comment", Canadian Journal of Economics and Political Science, 31, pp. 256-266.

Scherer, F.M. (1965b), "Firm Size, Market Structure, Opportunity, and the Output of Patented Inventions", American Economic Review 55, pp. 1097-1125.

Scherer, F.M. (1967), "Market Structure and the Employment of Scientists and Engineers", American Economic Review, 57, pp. 524-531.

Scherer, F.M. (1983a), "Concentration, R\&D, and Productivity Change", Southern Economic Journal, 50, pp. 221-225.

Scherer, F.M. (1983b), "The Propensity to Patent", International Journal of Industrial Organization, 1, pp. $107-128$.

Scherer, F.M. (1984), Innovation and Growth. Schumpeterian Perspectives, Cambridge, Mass.: MIT Press.

Scherer, F.M. (1991), "Changing Perspectives on the Firm Size Problem", in Z.J. Acs and D.B. Audretsch (eds.), Innovation and Technological Change. An International Comparison, Ann Arbor: University of Michican Press.

Scherer, F.M. (1992), "Schumpeter and Plausible Capitalism, Journal of Economic Literature 30, pp. 1416-1433.

Scherer, F.M. and K. Huh (1992), "R\&D Reactions to High-Technology Import Competition", Review of Economics and Statistics, 74, pp. 202-212.

Schmalensee, R. (1989), "Inter-Industry Studies of Structure and Performance", in R. Schmalensee and R.D. Willig (eds.), Handbook of Industrial Organization, Vol. II, Amsterdam: North-Holland.

Schmookler, J. (1966), Invention and Economic Growth, Cambridge, Mass.: Harvard University Press.

Schmookler, J. (1972), "The Size of Firm and the Growth of Knowledge", in J. Schmookler, Patents, Innovation and Economic Change, Cambridge, Mass.: Harvard University Press.

Scott, J.T. (1984), "Firm versus Industry Variability in R\&D Intensity", in Z. Griliches (ed.), $R \& D$, Patents, and Productivity, Chicago: University of Chicago Press.

Scott, J.T. (1993), Purposive Diversification and Economic Performance, Cambridge, Cambridge University Press.

Shrieves, R. (1978), "Market Structure and Innovation: A New Perspective", Journal of Industrial Economics, 26, pp. 329-347.

Soete, L.L.G. (1979), "Firm Size and Inventive Activity: The Evidence Reconsidered", European Economic Review, 12, pp. 319-340.

Sutton, J. (1991), Sunk Costs and Market Structure, Cambridge, Mass.: MIT Press. 
Sutton, J. (1995), "The Size Distribution of Businesses, Parts I and II, London School of Economics, mimeo.

Sutton, J. (1996), "Technology and Market Structure", European Economic Review, forthcoming.

Swann, P. and J. Gill (1993a), "The Speed of Technology Change and the Development of Market Structure: Semiconductors, PC Software and Biotechnology", in P. Swann, ed., New Technologies and the Firm. Innovation and Competition, London: Routledge.

Swann, P. and J. Gill (1993b), Corporate Vision and Rapid Technological Change, London: Routledge.

Switzer, L. (1984), "The Determinants of Industrial R\&D: A Funds Flow Simultaneous Equation Approach", Review of Economics and Statistics, 66, pp. 163-168.

Symeonidis, G. (1995), "Price Competition and the Evolution of Concentration: The Abolition of Pricefixing in British Manufacturing Industry", London School of Economics, mimeo.

Taylor, C.T. and Z.A. Silberston, 1973, The Economic Impact of the Patent System: A Study of the British Experience, Cambridge: Cambridge University Press.

Teece, D.J. (1992), "Competition, Cooperation, and Innovation: Organizational Arrangements for Regimes of Rapid Technological Progress", Journal of Economic Behavior and Organization, 18, pp. 1-25.

Utterbach, J.M. and F.F. Suarez (1993), "Innovation, Competition, and Industry Structure", Research Policy, 22, pp. 1-21.

Wedig, G.J. (1990), "How Risky Is R\&D? A Financial Approach", Review of Economics and Statistics, 72, pp. 296-303. 


\section{ECONOMICS DEPARTMENT}

\section{WORKING PAPERS}

A complete list of Working Papers is available on request.

160. Valuing the Right to Tax Incomes: An Options Pricing Approach (April, 1996) Teun Draaisma and Kathryn Gordon.

159. Innovation and Competitive Advantage

(October 1995) P. A. Geroski

158. Monetary Policy at Price Stability: A Review of Some Issues

(September 1995) Malcolm Edey, Norbert Funke, Mike Kennedy and Angel Palerm

157. Technical Progress, Factor Productivity and Macroeconomic Performance in the Medium Term (September 1995) Claude Giorno, Pete Richardson and Wim Suyker

156. Ageing Populations, Pension Systems and Government Budgets: How do they Affect Savings (August 1995) Willi Leibfritz, Deborah Roseveare, Douglas Fore and Eckhard Wurzel

155. The Determinants of Real Long-Term Interest Rates: 17 Country Pooled Time-Series Evidence (June 1995) Adrian Orr, Malcolm Edey and Michael Kennedy

154. An Assessment of Financial Reform in OECD Countries (May 1995) Malcolm Edey and Ketil Hviding

153. Markets for Tradeable $\mathrm{CO}_{2}$ Emission Quotas, Principles and Practice (February 1995) Graciela Chichilnisky and Geoffrey Heal

152. Estimating Potential Output, Output Gaps and Structural Budget Balances (January 1995) Claude Giorno, Pete Richardson, Deborah Roseveare and Paul van den Noord

151. $N O_{x} / S O_{x}$ Emissions and Carbon Abatement

(December 1994) Christophe Complainville and Joaquim O. Martins

150. The Determinants and Properties of Monetary Conditions: Direct Survey Evidence from New Zealand

(December 1994) Andreas Fischer and Adrian Orr

149. Health Care Reform: Controlling Spending and Increasing Efficiency

(December 1994) Howard Oxley and Maitland Macfarlan

148. Macroeconomic Performance and Fiscal Policy Adjustments in the Medium Term:

Alternative Medium-Term Scenarios

(September 1994) Pete Richardson, Claude Giorno and Stephan Thurman 
147. The EC's Internal Market: Implementation, Economic Consequences, Unfinished Business (August 1994) Peter Hoeller and Marie-Odile Louppe

146. Comparison of Model Structure and Policy Scenarios: GREEN and 12RT

(August 1994) Alan Manne and Joaquim O. Martins

145. An International Sectoral Data Base for Fourteen OECD Countries (Second Edition) (June 1994) F.J.M. Meyer zu Schlochtern and J.L. Meyer zu Schlochtern

144. Fiscal Policy, Government Debt and Economic Performance

(June 1994) Willi Leibfritz, Deborah Roseveare and Paul van den Noord

143. GREEN: The Reference Manual

(May 1994) Dominique van der Mensbrugghe

142. Pension Liabilities in the Seven Major Economies

(December 1993) Paul van den Noord and Richard Herd

141. The Distribution System in Sweden

(October 1993) Sören Wibe

140. The Distribution Sector in the United Kingdom

(October 1993) John A. Dawson

139. The Italian Distribution System

(October 1993) Luca Pellegrini and Angelo M. Cardani

138. The French Distribution Industry and the Openness of the French Economy

(October 1993) Patrick A. Messerlin

137. The German Distribution System

(October 1993) Josef Lachner, Uwe Chr. Täger, Gunther Weitzel

136. A Study of the Distribution System in Japan

(October 1993) Masayoshi Maruyama

135. An Analysis of the U.S. Distribution System

(October 1993) Roger R. Betancourt

134. Market Structure, International Trade and Relative Wages

(October 1993) Joaquim Oliveira Martins

133. The Economic Analysis of Institutions and Organisations -- in General and with respect to Country Studies

(September 1993) Oliver E. Williamson

132. High and Persistent Unemployment: Assessment of the Problem and its Causes

(September 1993) Jørgen Elmeskov 


\section{GENERAL DISTRIBUTION}

\section{ECONOMICS DEPARTMENT}

\section{WORKING PAPERS}

This series of Working Papers is designed to make available, to a wider readership, selected studies which the Department has prepared for use within OECD. Authorship is generally collective, but main individual authors are named. The Papers are generally available in their original language, English or French, with a summary in the other.

The views expressed in this paper are those of the author(s) and do not necessarily reflect those of the OECD or of the governments of its Member countries.

Comment on the Papers is invited, and may be sent to OECD, Economics Department, 2 rue AndréPascal, 75775 Paris Cedex 16, France. Additional copies of the Papers, on a limited basis can be forwarded on request. 